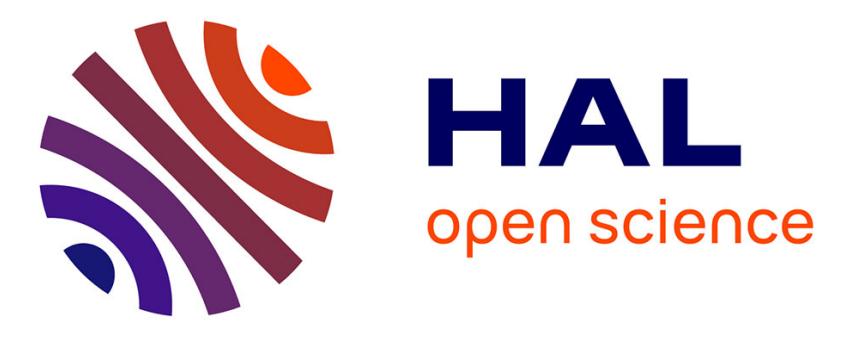

\title{
S-velocity model and inferred Moho topography beneath the Antarctic Plate from Rayleigh waves
}

Meijan An, Douglas Wiens, Yue Zhao, Mei Feng, Andrew Nyblade, Masaki Kanao, Yuansheng Li, Alessia Maggi, Jean-Jacques Lévêque

\section{- To cite this version:}

Meijan An, Douglas Wiens, Yue Zhao, Mei Feng, Andrew Nyblade, et al.. S-velocity model and inferred Moho topography beneath the Antarctic Plate from Rayleigh waves. Journal of Geophysical Research, 2015, 10.1002/2014JB011332 . hal-01239998

\section{HAL Id: hal-01239998 \\ https://hal.science/hal-01239998}

Submitted on 21 Oct 2021

HAL is a multi-disciplinary open access archive for the deposit and dissemination of scientific research documents, whether they are published or not. The documents may come from teaching and research institutions in France or abroad, or from public or private research centers.
L'archive ouverte pluridisciplinaire HAL, est destinée au dépôt et à la diffusion de documents scientifiques de niveau recherche, publiés ou non, émanant des établissements d'enseignement et de recherche français ou étrangers, des laboratoires publics ou privés. 


\section{Journal of Geophysical Research: Solid Earth}

\section{RESEARCH ARTICLE}

10.1002/2014JB011332

Key Points:

- High-resolution crust/lithosphere

$V s$ model covering the whole

Antarctic Plate

- Lithospheric mantle in most of

the Antarctica is significantly old and buoyant

- East Antarctic Mountain Ranges are a thick-crust belt

Supporting Information:

- Figure S1

- Figure S2

- Figure S3

- Figure S4

- Figure S5

- Figure S6

- Figure S7

- Table S1

- Text S1

Correspondence to:

M. An and D. A. Wiens,

meijianan@live.com;

doug@seismo.wustl.edu

Citation:

An, M., D. A. Wiens, Y. Zhao, M. Feng A. A. Nyblade, M. Kanao, Y. Li, A. Maggi, and J.-J. Lévêque (2015), S-velocity model and inferred Moho topography beneath the Antarctic Plate from Rayleigh waves, J. Geophys. Res. Solid Earth, 120, 359-383, doi:10.1002/ $2014 J B 011332$.

Received 28 MAY 2014 Accepted 12 DEC 2014 Accepted article online 18 DEC 2014 Published online 27 JAN 2015

\section{S-velocity model and inferred Moho topography beneath the Antarctic Plate from Rayleigh waves}

\author{
Meijian An ${ }^{1}$, Douglas A. Wiens ${ }^{2}$, Yue Zhao ${ }^{1}$, Mei Feng ${ }^{1}$, Andrew A. Nyblade ${ }^{3}$, Masaki Kanao ${ }^{4}$, \\ Yuansheng $\mathrm{Li}^{5}$, Alessia Maggi ${ }^{6}$, and Jean-Jacques Lévêque ${ }^{6}$ \\ ${ }^{1}$ Institute of Geomechanics, Chinese Academy of Geological Sciences, Beijing, China, ${ }^{2}$ Department of Earth and Planetary \\ Science, Washington University, St. Louis, Missouri, USA, ${ }^{3}$ Department of Geosciences, Pennsylvania State University, \\ University Park, Pennsylvania, USA, ${ }^{4}$ National Institute of Polar Research, Tokyo, Japan, ${ }^{5}$ Polar Research Institute in China, \\ Shanghai, China, ${ }^{6}$ Institut de Physique du Globe de Strasbourg, Université de Strasbourg/EOST, CNRS, Strasbourg, France
}

Abstract Since 2007/2008, seismographs were deployed in many new locations across much of Antarctica. Using the records from 122 broadband seismic stations, over 10,000 Rayleigh wave fundamental-mode dispersion curves have been retrieved from earthquake waveforms and from ambient noise. Using the processed data set, a 3-D S-velocity model for the Antarctic lithosphere was constructed using a single-step surface wave tomographic method, and a Moho depth map was estimated from the model. Using the derived crustal thicknesses, the average ratio of lithospheric mantle and crustal densities of Antarctica was calculated. The calculated density ratio indicates that the average crustal density for Antarctica is much higher than the average values for continental crust or the average density of lithospheric mantle is so low as to be equal to low-density bound of Archean lithosphere. The latter implies that the lithospheric mantle in much of Antarctica should be old and of Archean age. The East Antarctic Mountain Ranges (EAMOR) represent a thick crustal belt, with the thickest crust $(\sim 60 \mathrm{~km})$ located close to Dome A. Very high velocities can be found at depths greater than $200 \mathrm{~km}$ beneath parts of East Antarctica, demonstrating that the continental lithosphere extends deeper than $200 \mathrm{~km}$. The very thick crust beneath the EAMOR may represent the collision suture of East Gondwana with Indo-Antarctica and West Gondwana during the Pan-African orogeny.

\section{Introduction}

Antarctica (Figure 1) was part of the Gondwana supercontinent and was contiguous with other present-day continents (e.g., Africa, India, and Australia) prior to the breakup of Gondwana in the Late Mesozoic [Torsvik et al., 2010], see short overview on the evolution of the continent in the supporting information of this paper. The continent is mostly covered by ice sheets at present and is moving with only a slight rotational component in an absolute velocity reference frame [Bouin and Vigny, 2000; Torsvik et al., 2008]. Intracontinental seismicity is in a low level [Reading, 2007], even in the West Antarctic rift system (WARS) [Winberry and Anandakrishnan, 2003; LeMasurier, 2008]. The above conditions imply that no significant tectonic deformation of crust or lithosphere is presently occurring beneath the ice-covered continent: this is particularly true beneath East Antarctica (EANT). As such, information regarding its evolution, e.g., the amalgamation and evolution of the Gondwanaland ( 550-200 Ma) and even of the prior Rodinian ( 1100-750 Ma), may be still preserved in the crust and lithospheric mantle of Antarctica.

An understanding of the crustal and upper mantle structure of the Antarctic Plate is essential for understanding the mechanisms responsible for the assembly and breakup of Gondwana and the dynamics of plate motions since the Late Mesozoic [Sutherland, 2008; Torsvik et al., 2008]. However, geophysical data collection in the continent has been hindered by a combination of ice cover and logistical constraints [Bell, 2008; Block et al., 2009]; e.g., no broadband seismic stations were present on the broad interior area of EANT prior to 2007. The limited amount of intraplate seismicity has hindered passive-source seismological studies of the Antarctic lithosphere.

Since the Fourth International Polar Year (IPY) (2007-2008), intensive surveys have been conducted in Antarctica. In seismology, the Antarctic Network (ANET)-Polar Earth Observing Network (POLENET) project (2007 to present) significantly improved the coverage of seismic observations in West Antarctica (WANT). The Gamburtsev Antarctic Mountains Seismic Experiment (GAMSEIS, 2007-2010), part of Antarctica's Gamburtsev Province (AGAP) IPY project, involved deployment of broadband seismic stations (Figure 1) in EANT, 


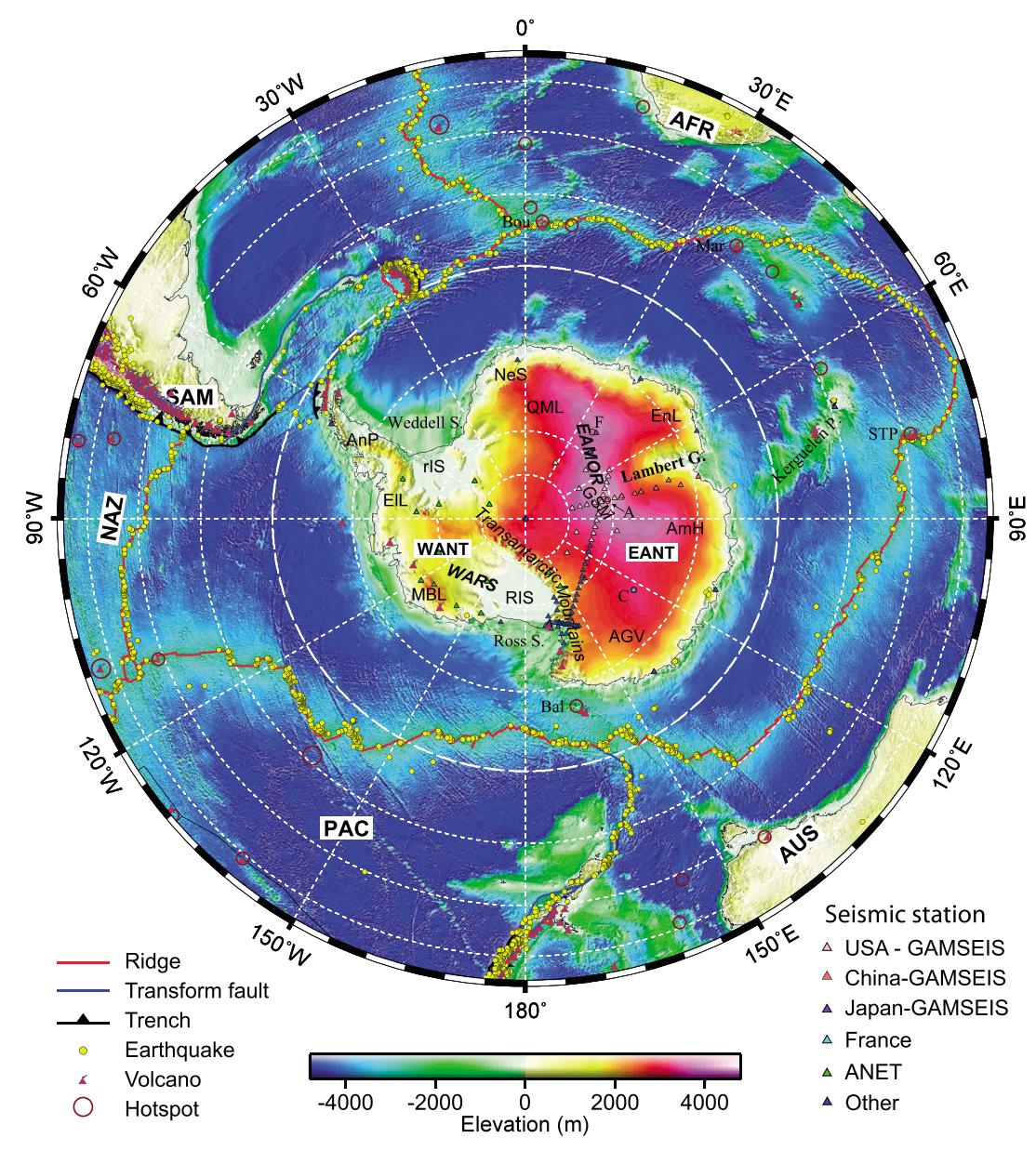

Figure 1. Topography of the Antarctic Plate. The shading is the surface topography from ETOPO2. All broadband seismic stations (triangles) and earthquakes shown are used in this study. $A=$ Dome $A$ (Argus), AFR = African Plate, AIS = Amery ice shelf, AmH = American Highland, AUS = Australian Plate, C = Dome C (Circe, Charlie), EANT = East Antarctica, EIL = Ellsworth Land, EnL = Enderby Land, F = Dome F (Fuji), GSM = Gamburtsev Subglacial Mountains, MBL = Marie Byrd Land, $\mathrm{NAZ}=$ Nazca Plate, NeS = New Schwabenland, PAC = Pacific Plate, $\mathrm{QML}=$ Queen Maud Land, $\mathrm{rlS}=$ Ronne ice shelf, RIS = Ross ice shelf, SAM = South American Plate, TAM = Transantarctic Mountains, and WANT = West Antarctica. The red circles are proposed hot spots at Foundation [Ito and van Keken, 2007], St. Paul Island [Müller et al., 1993], and elsewhere [Courtillot et al., 2003]. Hot spot abbreviations: Bal = Balleny, Bou = Bouvet, Mar= Marion, and STP = St. Paul-Amsterdam. Volcanoes were identified by the Global Volcanism Program of the Smithsonian Institution [Siebert and Simkin, 2002].

particularly in the Gamburtsev Subglacial Mountains (GSM) around Dome A (Dome Argus or Kunlun station), by the United States, China, and Japan. The Chinese stations are under the management of the Chinese Program of Antarctic Nova Disciplines Aspects. The GAMSEIS stations were located across previously unexplored areas of the interior of EANT. Data from all GAMSEIS stations in EANT and backbone ANET stations in WANT used here (Figure 1) are providing important information on the Antarctic Plate.

Surface waves propagating along the Earth's surface from source to receiver can be used to infer crustal and lithospheric structure beneath the propagation path, particularly in regions with a paucity of receiving stations and low seismicity, such as in Antarctica. Therefore, surface wave observations have been widely applied to the study of crustal and lithospheric structure [e.g., Evison et al., 1960; Dewart and Toksöz, 1965; Knopoff and Vane, 1978; Roult et al., 1994; Danesi and Morelli, 2001; Ritzwoller et al., 2001; Lawrence et al., 2006] and crustal thicknesses [e.g., Evison et al., 1960; Ritzwoller et al., 2001; Lawrence et al., 2006] beneath Antarctica. Surface wave studies of the Antarctic Plate prior to the Fourth IPY [e.g., Danesi and Morelli, 2001; Ritzwoller et al., 2001] have been severely restricted by the sparse seismic station distribution; thus, to more robust data requires a denser distribution of seismographs, particularly in the continental interior [Morelli and Danesi, 2004]. New observations obtained since the Fourth IPY not only permit investigation of regional 
crustal structures beneath the stations by receiver function analysis [e.g., Winberry and Anandakrishnan, 2004; Bayer et al., 2009; Hansen et al., 2009, 2010; Finotello et al., 2011; Chaput et al., 2014; Feng et al., 2014] but also provide better lateral resolution of surface waves at regional scale study around the GSM [Heeszel et al., 2013] and throughout the entire Antarctic Plate (this study), especially covering the regions, e.g., from Queen Maud Land (QML) to Ellsworth Land (EL), where the underlying crust and lithosphere have never been well studied by robust seismic exploration.

The main objective of this study is to construct a 3-D crustal and lithospheric seismic model for the entire Antarctic Plate using Rayleigh wave group velocities from the seismic waveforms (from earthquake and ambient noise) recorded by Antarctic seismic stations. Upper mantle S-velocity can be converted into temperature that more directly provides tectonic and geodynamic information than seismic velocity [Goes et al., 2000; McKenzie et al., 2005; An and Shi, 2006, 2007]. The mantle temperatures inferred from the S-velocity model of this study are introduced in a later paper of M. An et al. (manuscript in preparation, 2014).

The topography and character of seismic discontinuities provide important insights into crustal evolution. The Moho discontinuity at the base of the crust, first identified by Mohorovičić [1910], separates lighter granitic continental crust or basaltic oceanic crust from denser peridotitic upper mantle. Crustal thickness variations of Antarctica have been explored for decades [e.g., Evison et al., 1960; Lawrence et al., 2006; Baranov and Morelli, 2013], but until the Fourth IPY, the data were not sufficient to provide a crustal thickness map at reasonable resolutions covering all of Antarctica because most of broad EANT has never been measured. Even after the IPY, the Moho at some of the EANT has not been directly measured yet. Gravity observations are often used to define the relative topography of the Moho [Block et al., 2009; O'Donnell and Nyblade, 2014] using constraints provided where available from high-resolution Moho determinations. Active seismic and receiver function studies provided constraints on crustal thickness in Antarctica below seismic lines or recording stations [Baranov and Morelli, 2013, and references therein]. However, there is also merit in employing techniques, such as analyses of surface waves, that infer crustal thickness along wave propagation path which enable a broader coverage to be obtained. This is important in the case of the Antarctic continent where station coverage is sparse and no robust seismic exploration has yet been conducted in some regions. Here we construct a crustal thickness map for all of Antarctica (including unexplored areas) from the 3-D S-velocity model for the Antarctic Plate. This Moho map greatly improves the resolution of crustal thickness variations across Antarctica compared to previous crustal thickness models of the entire Antarctic continent.

\section{Data}

The seismic data used in this study are fundamental-mode Rayleigh wave group velocity measurements from earthquake waveforms and from interstation Green's functions derived using ambient noise cross correlation. To decrease the position error caused by station movement with underlying ice (e.g., with a rate of up to hundreds of meters per year) or reinstallation [An et al., 2014], we estimated the positions of GAMSEIS stations using year-round GPS records of the stations separated by field service time.

Vertical-component seismograms from events with a range of magnitudes and depths were selected for processing based on large theoretical amplitudes calculated from magnitude and event-station distance. Interstation Green's functions are obtained by cross correlation from vertical-component ambient noise. Rayleigh wave group velocities were measured from the seismograms and Green's functions using a multiple filtering technique [Dziewonski et al., 1969] with phase-matched processing [Herrin and Goforth, 1977] to isolate the fundamental-mode surface waves. We used a modified program of do_mft from Herrmann and Ammon [2002], in which instantaneous frequency is preferred, in order to take into account the spectral amplitude variation [Nyman and Landisman, 1977] for each nominal frequency of analysis. The primary modification was the use of a filter whose width varies with the filtered period [Feng et al., 2004].

The number and distribution of dispersion measurements can directly influence the reliability of the final inverted S-velocity model. Here we provide a brief description of our retrieved data set. We only used the dispersion measurement when the entire propagation path is south of latitude $-24^{\circ}$. We retrieved 10,160 valid dispersion curves, which are from 122 broadband seismic stations and from 1917 earthquakes (Figure 1) prior to March 2013. Figure 2a shows the number of Rayleigh wave group velocities used for each period. The measurements from ambient noise (Figure 2a) are a small part of all measurements used here. 
(a)

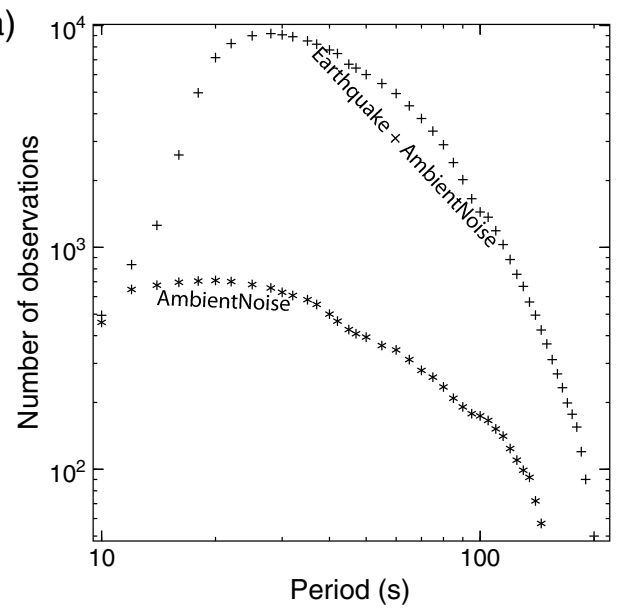

(b)

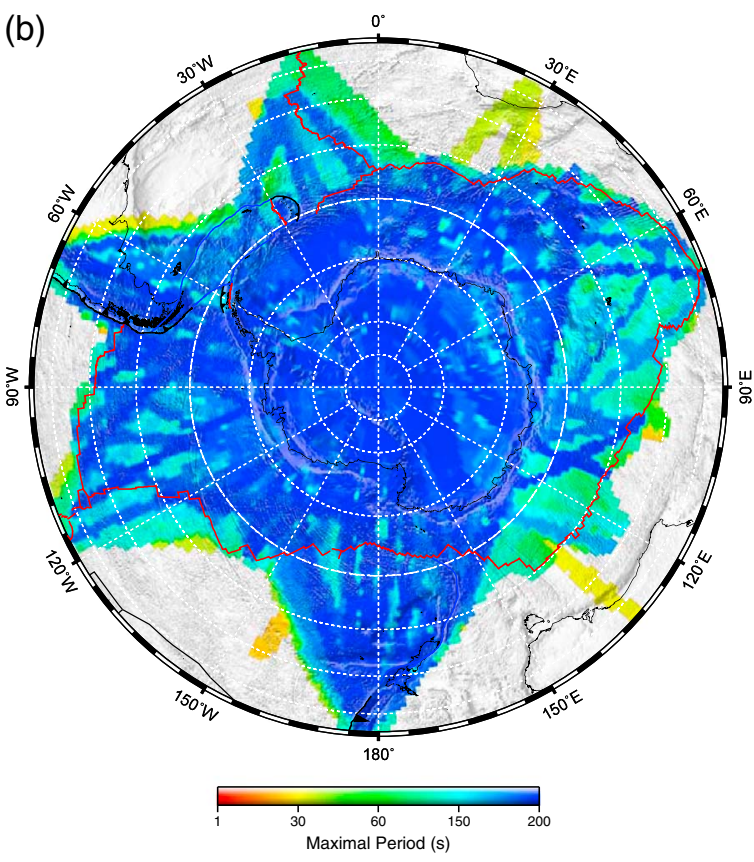

Figure 2. (a) Number of group velocity observations for each period and (b) maximum period of the surface wave group velocity at each position used in this study. Other features in Figure $2 b$ are the same as in Figure 1.
The number of all measurements was 9187 for a period of $28 \mathrm{~s}$, and the number of measurements for short ( $<20 \mathrm{~s}$ ) and long periods ( $>60 \mathrm{~s}$ ) was much smaller than those for intermediate periods (20-60 s). Figure $2 \mathrm{~b}$ shows the maximum period of the dispersion measurements at each position. Figure 3 presents a lateral discretization of the study region in the form of equal-area pentagonal and hexagonal cells along with the path-density distribution for periods of $30,50,100$, and $150 \mathrm{~s}$. Most continental regions have a density of $>50$ rays per $\sim 120 \mathrm{~km}$ cell at intermediate periods (20-60 s) and $>10$ rays at long periods of $100 \mathrm{~s}$ (Figure 3). The dense path coverage at periods of 20-60 s ensures a good resolution in the resultant model at depths around the continental Moho discontinuity, given that the continental crust is $<80 \mathrm{~km}$ thick [Mooney et al., 1998; Laske et al., 2000]. Our dispersion observations have a good coverage for observations with periods of up to about $100 \mathrm{~s}$ in most oceanic regions and up to about $150 \mathrm{~s}$ in most continental regions (Figure $2 \mathrm{~b}$ ). This ensures good resolution in the resultant model at depths close to the lithosphere-asthenosphere boundary throughout Antarctica, given that the oceanic lithosphere thickness is $\sim 100 \mathrm{~km}$ and continental lithosphere can be as thick as $200 \mathrm{~km}$ [Artemieva and Mooney, 2001; Jackson et al., 2008; Fischer et al., 2010].

In order to improve the resolution near the plate boundary, we experimented with adding phase velocities provided in previous global studies [e.g., Ekström et al., 1997; Trampert and Woodhouse, 2001]. However, these data did not improve our model perhaps because of the paucity of Antarctic stations used in these previous studies.

\section{Methods}

Rather than using a traditional two-step process (i.e., period-by-period 2-D surface wave dispersion tomography followed by cell-by-cell 1-D S-velocity inversions), a 3-D S-velocity model was directly inverted from fundamental-mode Rayleigh wave group velocities using an improved version of the single-step surface wave tomographic method proposed by Feng and An [2010], in which the inversion equation is

$$
\left(\begin{array}{c}
T-C \\
0
\end{array}\right)=\left(\begin{array}{c}
A \\
\lambda \nabla
\end{array}\right) \cdot B,
$$

where $T$ is the travel time vector, $C$ is a constant vector, $A$ is a coefficient matrix, and $B$ is the vector of 3-D $S$-velocity perturbations to be determined; $\lambda$ is a weighting factor to balance between the fitting of the travel times and model smoothing, 3-D first-order spatial gradient $(\nabla)$ of the model. The basic concepts of this approach are summarized in the supporting information of this paper, but a detailed description of the inversion for a 3-D model from surface wave dispersions can be found in Feng and An [2010]. 

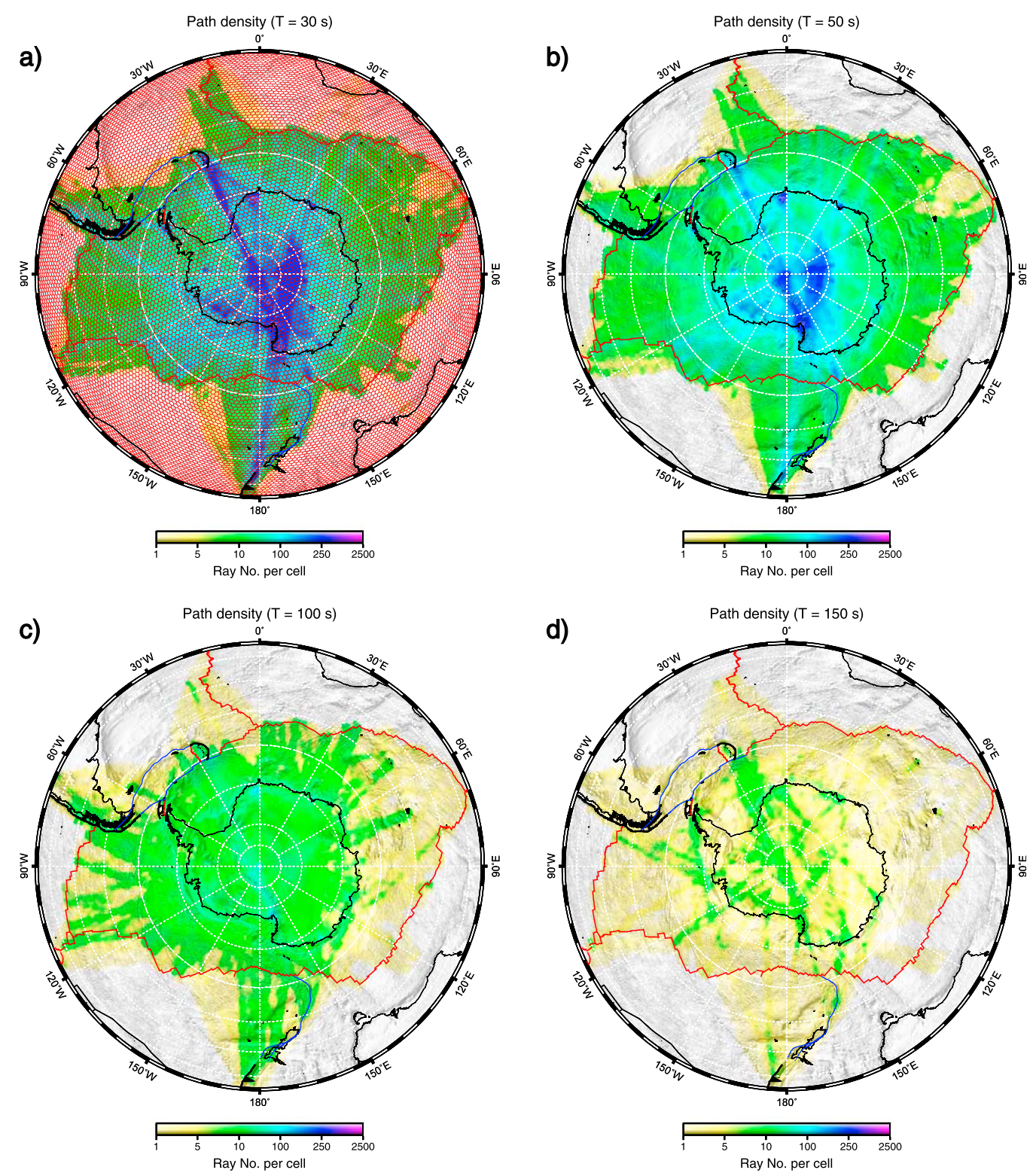

Figure 3. Propagating path density of group velocity measurements at periods of (a) $30 \mathrm{~s}$, (b) $50 \mathrm{~s}$, (c) $100 \mathrm{~s}$, and (d) $150 \mathrm{~s}$. The study region was laterally discretized as equal-area cells, which are bordered by red lines in Figure $3 a$ and which have a great circle extent of $\sim 1^{\circ}\left(1^{\circ}=111 \mathrm{~km}\right)$. The path density is defined as the number of propagation paths that intersect each cell. Other features in the figure are the same as in Figure 1.

The primary improvement of the method used here over Feng and An [2010] is to use equal-area pentagonal and hexagonal cells [Sahr et al., 2003] in horizontal (Figure 3a) rather than traditional quadrangular cells, because equal-area cells are better than quadrangular cells for tomographic studies in polar regions. To adopt a cell with a complex form such as a pentagon or hexagon, most of the basic tomographic procedures for ray tracing through to model appraisal have to be redesigned. For example, new methods need to be developed to estimate model spatial resolution [An, 2012], because simple checkerboard synthetic tests cannot be used for pentagonal and hexagon cells. A secondary improvement is to use Moho discontinuity data as constraints, which is introduced below.

\subsection{Spatial Resolution}

We retrieved resolution dimensions for the seismic model by simple methods proposed specifically for this study by $A n$ [2012]. The detailed spatial resolution analysis and resolution information can be found in the 
supporting information of this paper. Here we give a short summary of the models' spatial resolution lengths which are defined as half of the recovered dimension.

We first retrieve quantitative resolution lengths for the 2-D surface wave dispersion measurements, which are useful in evaluating the lateral resolution of a surface wave study, by using the statistical resolution length calculation proposed by An [2012]. The results (Figure S3 in the supporting information) show that the horizontal resolution length of our model in the whole continent can be $\sim 100 \mathrm{~km}$ for a period of $50 \mathrm{~s}$ and $\sim 250 \mathrm{~km}$ for a period of $150 \mathrm{~s}$ and in the oceanic areas are $\sim 200$ and $\sim 500 \mathrm{~km}$, respectively.

A visualization of an inverted solution model from a random synthetic model can provide not only resolution length information but also the directional dependence of the resolution [An, 2012]. The inverted 3-D solutions (Figure S4 in the supporting information) using random synthetic 3-D models, based on the actual surface wave paths, indicate that the horizontal resolution length is $\sim 120 \mathrm{~km}$ at a depth of $50 \mathrm{~km}, \sim 250 \mathrm{~km}$ at a depth of $120 \mathrm{~km}$, and $\sim 400 \mathrm{~km}$ at a depth of $200 \mathrm{~km}$ beneath the GSM. The resolution length along the meridian is larger than that along the line of latitude, particularly for the oceanic region, given that most of the observation stations are located inside continental Antarctica and that the earthquakes are coming from the plate boundaries (Figure 1). In the oceanic region close to Marie Byrd Land (MBL), the resolution length at a depth of $50 \mathrm{~km}$ is $\sim 150 \mathrm{~km}$ along the line of latitude and $\sim 500 \mathrm{~km}$ along the meridian. In general, the resolution length is $\sim 500 \mathrm{~km}$ at a depth of $120 \mathrm{~km}$ and $\sim 750 \mathrm{~km}$ at a depth of $200 \mathrm{~km}$. Similar to horizontal resolution length, the vertical resolution length increases with increasing depth, which is indicated from sensitivity kernels in Figure S5 in the supporting information. For example, beneath the GSM, the vertical resolution lengths are $\sim 10 \mathrm{~km}$ down to $60 \mathrm{~km}, \sim 25 \mathrm{~km}$ down to $150 \mathrm{~km}$, and $\sim 50 \mathrm{~km}$ down to $250 \mathrm{~km}$. The resolution of a discontinuity is higher than that of the velocity at a position around the discontinuity $[A n, 2012]$. The vertical resolution length for the Moho depth (mostly $<60 \mathrm{~km}$ ) retrieved from the 3-D model is $<10 \mathrm{~km}$ and for the seismic lithosphere-asthenosphere boundary (at the depths of $\sim 100-250 \mathrm{~km}$ ) is $<25-50 \mathrm{~km}$.

\subsection{Moho Constraints}

A priori information constraining crustal thickness can help improve inversion for the 3-D lithospheric structure. Here the $S$-velocity increase from the bottom of the crust, just above the a priori Moho position, to the top of the upper mantle is considered as constraints in the inversion, and as such, the inversion (equation (1)) becomes

$$
\left(\begin{array}{c}
T-C \\
0 \\
\lambda_{C} \boldsymbol{C}
\end{array}\right)=\left(\begin{array}{c}
A \\
\lambda \nabla \\
\lambda_{C} \nabla_{c}
\end{array}\right) \cdot B,
$$

where $\nabla_{c}$ represents the $S$-velocity difference between the layers just below and above the Moho, $\lambda_{c}$ is a weighting factor, and $c$ is a constant for each crustal thickness constraint. Considering that the preliminary reference Earth model [Dziewonski and Anderson, 1981] shows an S-velocity increase of $\sim 0.59 \mathrm{~km} / \mathrm{s}$ just across the Moho, we set the $S$-velocity difference at the Moho to be $0.5 \mathrm{~km} / \mathrm{s}$, and therefore, $c$ is the offset between this value $(0.5)$ and the velocity difference $\left(\nabla_{c}\right)$ given in the reference model.

We have compiled crustal thickness estimates from previous active seismic and receiver function studies, as detailed in the next section. In order to check the influence of the a priori Moho information on our inversion from surface waves, we inverted for a 3-D S-velocity model using our dispersion observations using equation (1). Taking this model as a new reference model, we inverted for two new 3-D S-velocity models without and with Moho constraints, respectively, using equations (1) and (2). Figure S6 in the supporting information shows the resulting $S$ velocities. As expected, a priori Moho constraints at a particular location sharpen the discontinuity at the expected Moho depth (Figure S6b in the supporting information), relative to the case with no Moho constraints. However, the influence in vertical direction on S-velocities at depths far from the Moho is very small and can be ignored (Figure S6b in the supporting information), and the influence in horizontal direction beneath neighboring regions is also insignificant (Figures S6c and S6d in the supporting information).

\subsection{Compilation of Previous Antarctic Moho Depth Measurements}

We collected crustal thickness and/or Moho depth data from previous seismic studies (not including surface wave studies), and made a compilation of ANtarctic Moho positions (AN-Moho; Figure 4), under the 


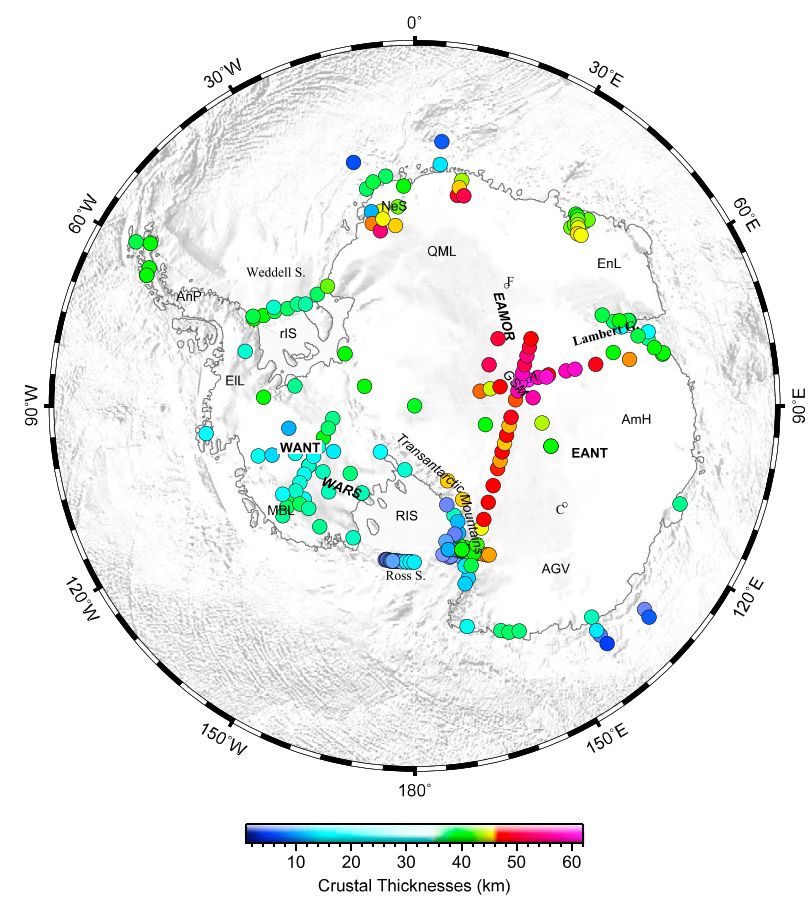

Figure 4. Compilation of Antarctic Moho depths from previous studies (AN-Moho). All the data and references are listed in Table S1 in the supporting information. evaluation of the quality of Moho depths. Considering that the crustal thickness or Moho depth given in previous studies may be variably defined, we corrected all thickness data to the same crustal thickness definition. Therefore, slight differences are evident between the data of our AN-Moho as compared with previous compilations and data presented in previous studies because of different definitions. The compilation of AN-Moho shows that no seismically derived Moho information is available for the large region from Queen Maud Land (QML), Dome F, to Ellsworth Land (EL). The Moho depths compiled in AN-Moho and more details of how this compilation was constructed can be found in the supporting information of this paper.

\subsection{Estimation of the Moho Position From Seismic Velocities}

Generally, the Moho is defined as where the compressional wave velocity increases rapidly or discontinuously to a $P$-velocity value between 7.6 and $8.6 \mathrm{~km} / \mathrm{s}$ [Thybo et al., 2013]. In the absence of a sharp velocity increase, it is taken to be the position at which the $P$ velocity first exceeds $7.6 \mathrm{~km} / \mathrm{s}$ [Steinhart, 1967; Durrheim and Mooney, 1994; Thybo et al., 2013]. Considering to an average Poisson ratio of 0.265 for continental crustal rocks [Christensen, 1996], the Moho can also be inferred from where $V_{s}$ first exceeds $4.3 \mathrm{~km} / \mathrm{s}$. However, vertical smearing or smoothing used in an S-velocity inversion from surface waves can result in a lower $S$ velocity in the inverted model at the real Moho position than in the real structure. Therefore, a velocity (e.g., $4.2 \mathrm{~km} / \mathrm{s}$ ), which is slightly lower than $4.3 \mathrm{~km} / \mathrm{s}$, can reasonably be taken as a preliminary indicator of the velocity at the Moho. However, seismic character of the Moho is variable between locations with different tectonic histories [Christensen and Mooney, 1995; Mooney, 2007], and fixed velocities cannot account for the various offsets between the Moho and seismic velocity in different tectonic units in a large region, which is shown in the result section here.

Considering both the velocities and the velocity variation sharpness in the vicinity of the Moho, we propose an equation to estimate the Moho depth or crustal thickness $(H)$ from seismic velocities by a weighted average of the depths for several velocities $\left(V_{i}\right)$, which are possibly at the Moho:

$$
H=\frac{\sum_{i}\left(w_{i} \cdot H_{V_{i}}\right)}{\sum_{i} w_{i}}, \quad w_{i}=\left\{\begin{array}{cc}
a \cdot \Delta V_{i} & \Delta V_{i}>0 \\
0 & \Delta V_{i} \leq 0
\end{array},\right.
$$

where $H_{V i}$ is the depth with $V_{i}, \Delta V_{i}$ is the velocity increase from $V_{i}$ to that at the layer just beneath the layer with $V_{i}$, and $a$ is a big constant (100 is used here on the basis of tests). From equation (3), the resulting Moho is not only at the position which has a possible $S$ velocity at the Moho but also with a sharp increase in seismic velocities, in accord with the general definition of the Moho.

\section{Results}

We parameterized the study region into 12,163 cells with lateral extents of $\sim 120 \mathrm{~km}$ (Figure 3a) and 51 layers in depth (Figure 5). The thicknesses of the vertical layers are $2.5 \mathrm{~km}$ at depths down to $20 \mathrm{~km}, 5 \mathrm{~km}$ between depths of 25 and $165 \mathrm{~km}, 10 \mathrm{~km}$ between depths of 170 and $250 \mathrm{~km}, 25 \mathrm{~km}$ between depths of 275 and $325 \mathrm{~km}$, and a half space at greater depths. All raypaths (such as those in Figures $3 \mathrm{a}-3 \mathrm{~d}$ ) used are inside the 

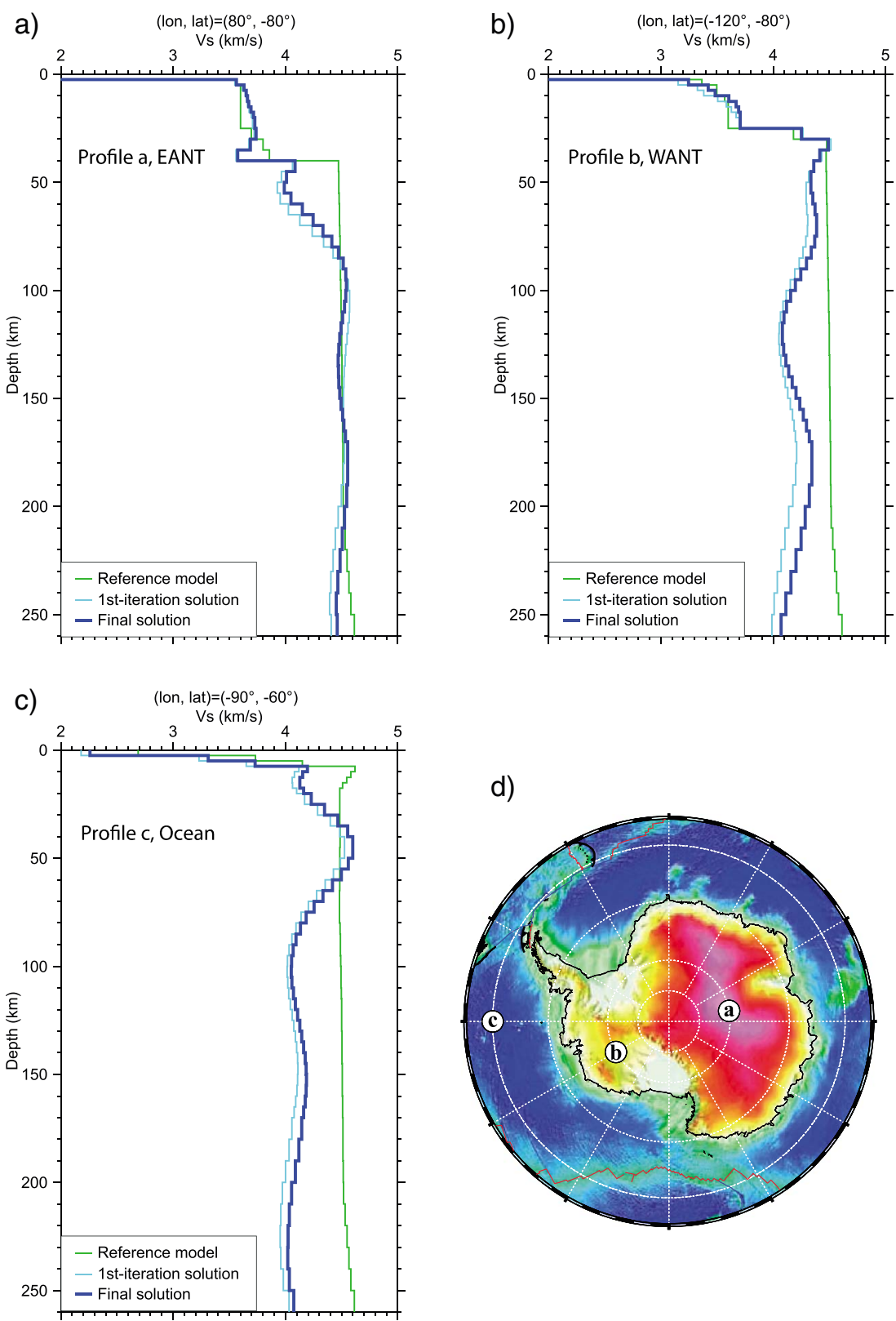

Figure 5. Representative 1-D S-velocity profiles for (a) EANT, (b) WANT, and (c) oceanic regions. The profiles in Figures 5a-5c are, respectively, beneath the positions labeled with " $a$, " " $b$," and "c" in Figure $5 \mathrm{~d}$. The age of the oceanic crust at the position of $\mathrm{c}$ is $\sim 60 \mathrm{Myr}$. The lines represent $S$ velocities of the reference model and inverted solutions.

study region (Figure 3a). The conjugate gradient method LSQR [Paige and Saunders, 1982a, 1982b] was used to invert for models. Parallel computation was added to the LSQR codes in order to improve computational efficiency. The initial reference model was constructed by combining CRUST2.0 and International Association of Seismology and Physics of the Earth's Interior (IASPEI) 91, with the crustal structure taken from CRUST2.0 [Bassin et al., 2000] and the upper mantle structure from IASPEI91 [Kennett and Engdahl, 1991]. As such, we denote the initial reference model as CRUST2.0 + IASPEI91. Using Rayleigh wave group velocities, we obtained a 3-D $S$-velocity model by inverting equation (1) without any Moho constraint. Taking this model as a new reference model, we then inverted for a final 3-D S-velocity model beneath the Antarctic Plate using equation (2) with crustal thickness constraints from AN-Moho. Given that our 3-D model has a lateral resolution length of $\sim 1^{\circ}$ for the crust in most of Antarctica (Figure S3C in the supporting information), we named the S-velocity model AN1-S. Because we did not consider azimuthal anisotropy in the inversion, the AN1-S model describes isotropic 
SV velocity. The model of AN1-S fit our dispersion data better than CRUST2.0 + IASPEI91 in all periods, particularly in periods of $<60 \mathrm{~s}$ and $>150 \mathrm{~s}$; we observed a mean variance reduction of $76 \%$ in fitting our dispersion data in all periods relative to CRUST2.0 + IASPEI91.

For a strongly and laterally heterogeneous area, such as at the continent-ocean boundary, an S-velocity model retrieved from surface wave dispersion can show general velocity variation trends in the vertical direction. However, the detailed vertical variations of the determined velocities may be artificial [An and Assumpção, $2005,2006]$; consequently, we do not interpret the detailed structure just beneath continent-ocean transition zones where the lateral structural variation may be marked over a short distance.

Moho depths and crustal thicknesses referred to below are the distance from the solid surface to the Moho. We note that this definition of Moho depth is different from that in the compilation of AN-Moho (Table S1 in the supporting information).

\subsection{Three-Dimensional S-Velocity Structure Model}

4.1.1. Representative 1-D Profiles

Figure 5 shows three examples of 1-D S-velocity profiles, which have been selected based on the new, broad-scale models that we have derived. The three profiles are used as representative of significant regions beneath EANT, WANT, and oceanic parts of the Antarctic Plate, respectively.

Figure $5 \mathrm{a}$ is a representative profile beneath the GSM, EANT. An S velocity of lower than $2 \mathrm{~km} / \mathrm{s}$ in the top layer (Figure 5a) represents ice covering in Antarctica. At depths of 40-70 km, the inverted seismic velocities are obviously lower than the upper mantle velocities from IASPEI91 (the upper mantle velocities in the initial reference model). If $4.2 \mathrm{~km} / \mathrm{s}$ is taken as the velocity at the Moho, then the Moho is $\sim 60 \mathrm{~km}$ deep in the 1-D profile, which is clearly larger than $\sim 40 \mathrm{~km}$ deep from the CRUST2.0 model (the crust thickness in the initial reference model), indicating a very thick crust beneath the GSM, in agreement with recent studies [Hansen et al., 2010; Heeszel et al., 2013; Feng et al., 2014]. At depths of 200-250 km, S-velocities decrease downward with depth, which indicates that the top of the seismic low-velocity zone (LVZ), also called seismic lithosphere-asthenosphere boundary, is at a depth of greater than $200 \mathrm{~km}$.

Figure $5 b$ shows a profile in WANT in the region of the West Antarctic rift system (WARS). In this region, the crust is thin and $\sim 25 \mathrm{~km}$ thick. Upper mantle $S$ velocities decrease with depth at depths of $\sim 80-110 \mathrm{~km}$, indicating that the upper bound of the seismic LVZ is no deeper than $100 \mathrm{~km}$.

Figure $5 \mathrm{c}$ is a representative profile beneath an oceanic region where the crust is very thin $(<10 \mathrm{~km})$. At the top of the upper mantle, the velocities at depths of $10-30 \mathrm{~km}$ are lower than that at the depth of $40 \mathrm{~km}$. These low velocities may result from lateral smoothing along propagation paths because observational paths crossing oceanic region have part of their path length through the Antarctic continent, where the crust extends through this depth range. Upper mantle $S$ velocities decrease with depth at the depths of $\sim 50-90 \mathrm{~km}$, which indicates that the upper bound of the seismic LVZ is no deeper than $80 \mathrm{~km}$.

In total, the above three profiles in EANT, WANT, and oceanic region show that both the crust and seismic lithosphere beneath GSM-EANT are thicker than those beneath WARS-WANT, which are thicker than beneath oceanic region.

\subsubsection{Representative Horizontal Slices}

The S-velocity maps at depths of 30,100, 150, and $200 \mathrm{~km}$ are shown in Figure 6. At a depth of $30 \mathrm{~km}$ (Figure 6a), all of the velocities in EANT (e.g., the structure in Figure 5a) are still part of the crust; however, at this depth, most of the velocities in WANT are near the base of the crust or at the top of the upper mantle (e.g., that in Figure 5b). Oceanic regions at a depth of $30 \mathrm{~km}$ are in the upper mantle. Figure 6a shows the large-scale lateral velocity variation beneath the Antarctic Plate from low velocities (in crust) beneath EANT to high velocities (in upper mantle) beneath oceanic regions.

The $S$-velocity maps at the depths of 100,150 , and $200 \mathrm{~km}$ show a very low velocity of $\sim 3.9 \mathrm{~km} / \mathrm{s}$ in the asthenosphere (oceanic lithosphere is thinner than $100 \mathrm{~km}$, as shown in Figure $5 \mathrm{c}$ ) beneath some places in the oceanic region. These extremely low velocities may be due to the low resolution and accuracy of $S$ velocities at these depths in the oceanic region because the resolution of $S$ velocities derived from surface wave observations decrease with the depth. Low path density of the long-period surface waves (Figure 3), which primarily constrain the upper mantle structure, in the oceanic region also resulted in a large uncertainty in the 

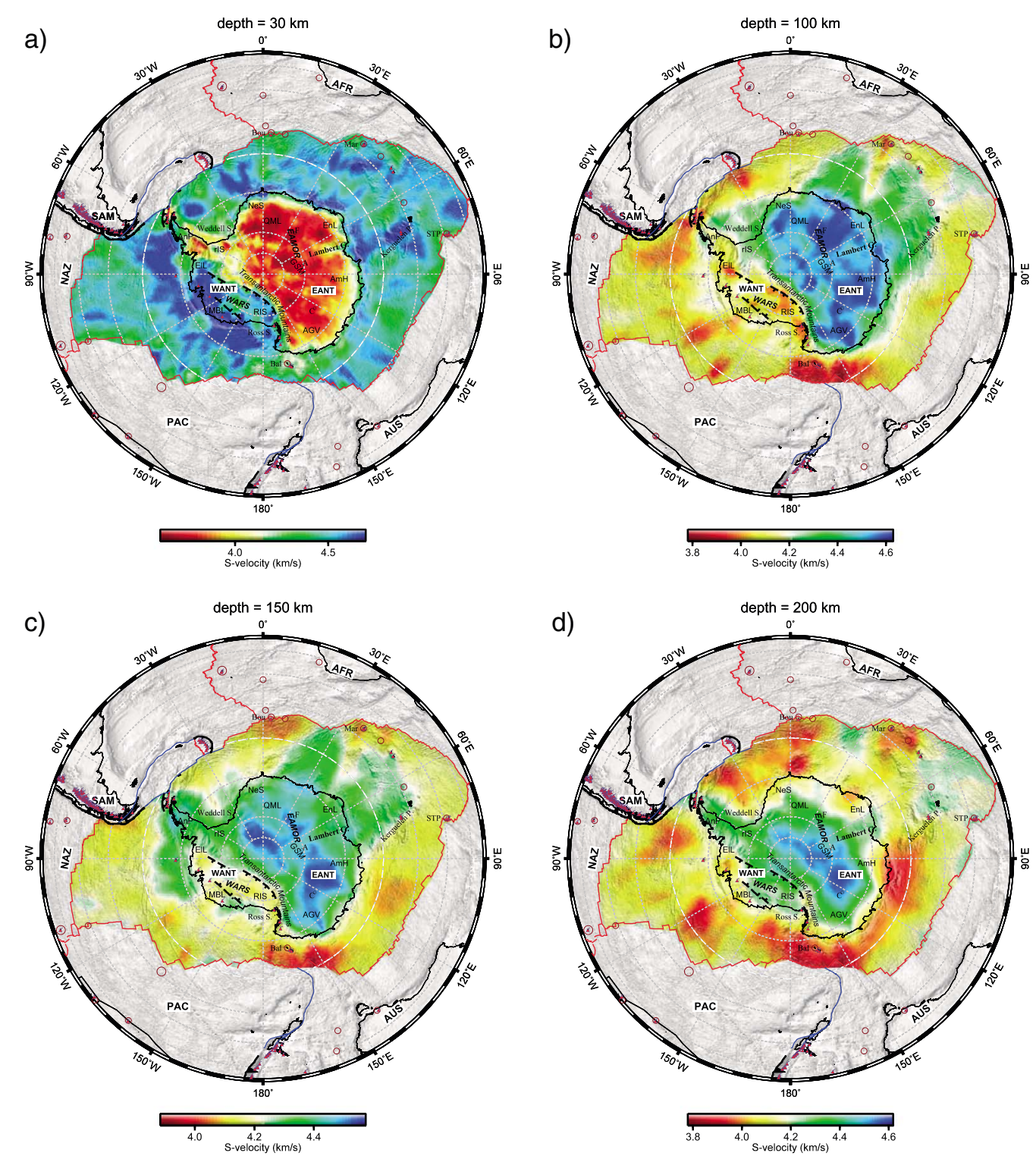

Figure 6. S-velocity maps at depths of (a) $30 \mathrm{~km}$, (b) $100 \mathrm{~km}$, (c) $150 \mathrm{~km}$, and (d) $200 \mathrm{~km}$. The symbols and labels are the same as in Figure 1.

deeper structure beneath this region. However, the anomaly patterns of the low velocities should be true because the half extents of the anomalies are close to or longer than the resolution lengths (Figures S3 and S4 in the supporting information) of our model at the these depths (100, 150, and $200 \mathrm{~km}$ ). Furthermore, the extremely low velocities in Figure $6 \mathrm{c}$ in our model are mostly beneath hot spots, such as Balleny hot spot (Bal), Marion hot spot (Mar), and Bouvet hot spot (Bou), beneath which an extremely low velocity in the asthenosphere is expected, suggesting that these low-velocity values in our model are reasonable.

At a depth of $100 \mathrm{~km}$ (Figure $6 \mathrm{~b}$ ), all of the Antarctic Plate is in the upper mantle; however, some regions are in the lithosphere and some are in the asthenosphere. According to the lithosphere thicknesses implied from the 1-D profiles in Figure 5, EANT at the depth of $100 \mathrm{~km}$ is still in the high-velocity seismic lid (or seismic lithospheric upper mantle), whereas for WANT, $100 \mathrm{~km}$ depth represents the base of the lithosphere and for oceanic regions, $100 \mathrm{~km}$ depth is in the asthenosphere. In oceanic regions from $0^{\circ} \mathrm{E}$ and $140^{\circ} \mathrm{E}$, there is a high-velocity zone relative to the other oceanic regions, particularly beneath the area from $20^{\circ} \mathrm{E}$ and $100^{\circ} \mathrm{E}$, where the velocities are similar to those beneath EANT. 

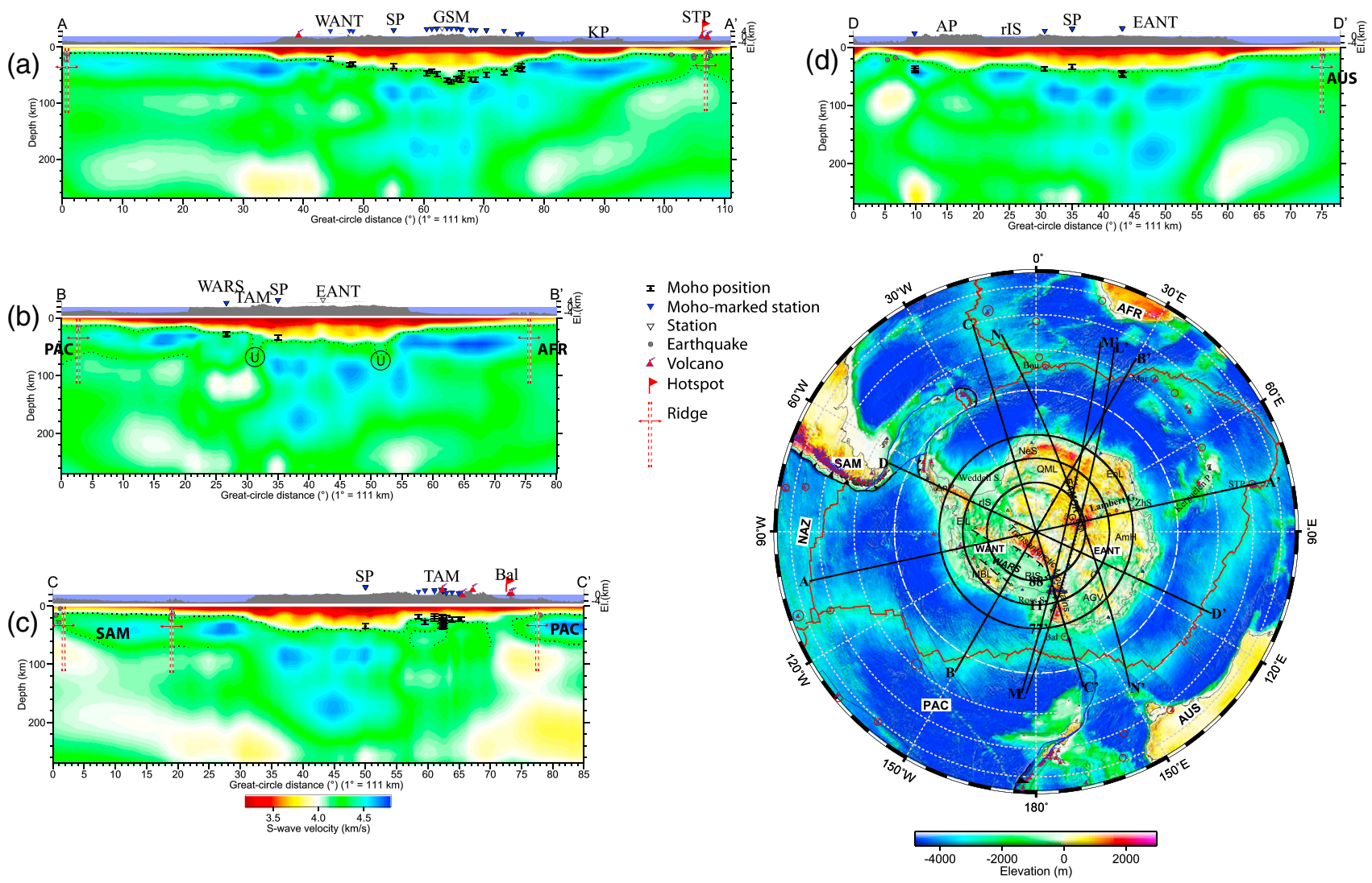

Figure 7. Representative S-velocity vertical transects. The transects (a-d) cross the South Pole, (e-g) cross the GAMSEIS array, and (h-j) are along latitudes of $70^{\circ} \mathrm{S}, 75^{\circ} \mathrm{S}$, and $80^{\circ}$ S, respectively. Transect A-A' (Figure 7a) crosses the South Pole, GSM, and the St. Paul-Amsterdam hot spot (STP). Transect B-B' (Figure 7b) crosses WANT, South Pole, and EANT. Transects L-L' (Figure 7e) and M-M' (Figure 7f) cross the TAM and GSM, respectively. Transect N-N' (Figure 7g) crosses Domes A and C. All transect positions are shown in the inset plot, in which shading is the Antarctic bedrock surface from Bedmap2 [Fretwell et al., 2013] and in other areas is the surface topography from ETOPO2. For each transect, the black and gray shaded areas indicate the continental and oceanic exaggerated topography, respectively. The black dots with error bars beneath the inverted blue-filled triangles mark the Moho positions from AN-Moho. All the inverted white-filled triangles and most of the blue-filled triangles are seismic stations used in this study. Earthquakes shown are from 1900 to 2007 taken from the EHB catalog [Engdahl et al., 1998]. The black dots mark the $4.2 \mathrm{~km} / \mathrm{s}$ isovelocity contour of the inverted solution. KP= Kerguelen Plateau, SP= South Pole, and ZhS = Zhongshan. The others are the same or from the same sources as in Figure 1. The circles labeled with $U$ mark the positions that the $4.2 \mathrm{~km} / \mathrm{s}$ isovelocity contour is too deep.

In Figure $6 \mathrm{~d}$, the $200 \mathrm{~km}$ deep map still shows high velocities ( $>4.5 \mathrm{~km} / \mathrm{s}$ ) beneath parts of East Antarctica, demonstrating that the continental lithosphere extends deeper than $200 \mathrm{~km}$. In detail, the highest velocities can be found at the large region from the GSM (Dome A) to Dome C (Figure 6d), beneath which thickest lithospheres of the Antarctic Plate should be located.

\subsubsection{Representative Vertical Transects}

Ten representative S-velocity transects are shown in Figure 7. Transects from A-A' to $D-D^{\prime}$ in Figures $7 a-7 d$

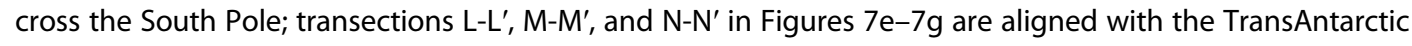
Mountains Seismic Experiment (TAMSEIS) and GAMSEIS arrays; and transections 7-7', 1-1', and 8-8' in Figure $7 \mathrm{~h}-7 \mathrm{j}$ are along latitudes of $70^{\circ} \mathrm{S}, 75^{\circ} \mathrm{S}$, and $80^{\circ} \mathrm{S}$, respectively. The TAMSEIS and GAMSEIS projects deployed linear arrays across the Transantarctic Mountains (TAM) and the GSM. All of the data obtained in these two projects were used in this study, and therefore, the four transects ( $A-A^{\prime}, L-L^{\prime}, M-M^{\prime}$, and N-N') in Figure 7 have good resolution due to the proximity of the seismic stations.

As pointed out previously, a velocity of $4.2 \mathrm{~km} / \mathrm{s}$ can be taken as preliminary indicator of the Moho. While this definition may be arbitrary, Moho depths in the compilation of previous Moho determinations (AN-Moho) can be used as a reference to evaluate if the Moho topography corresponds to the isovelocity contour in our model. Given this, we have annotated the Moho from AN-Moho, along with the $4.2 \mathrm{~km} / \mathrm{s}$ isovelocity contour, in the transects shown in Figure 7. Before comparing Moho depths (mostly derived from receiver functions) 


\section{AGU Journal of Geophysical Research: Solid Earth}
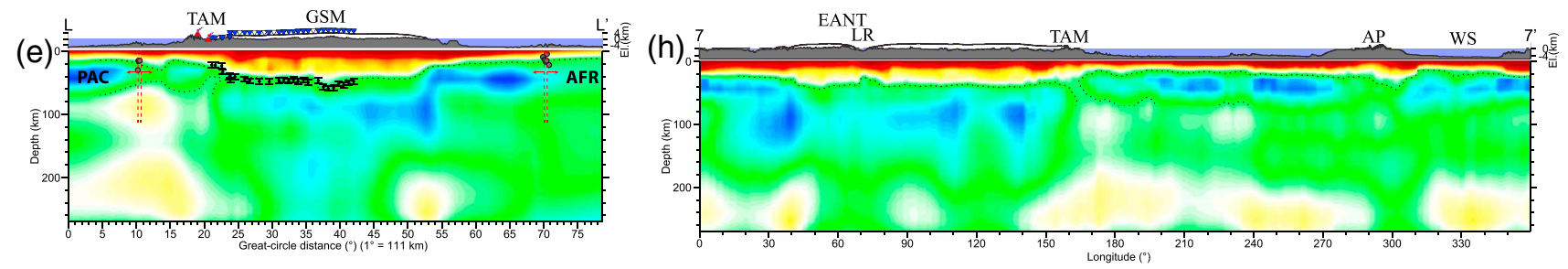

(f)
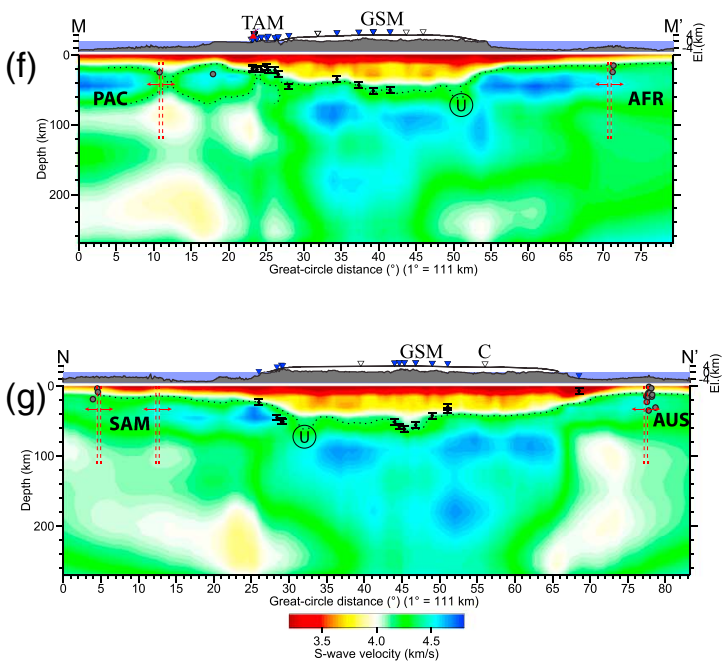
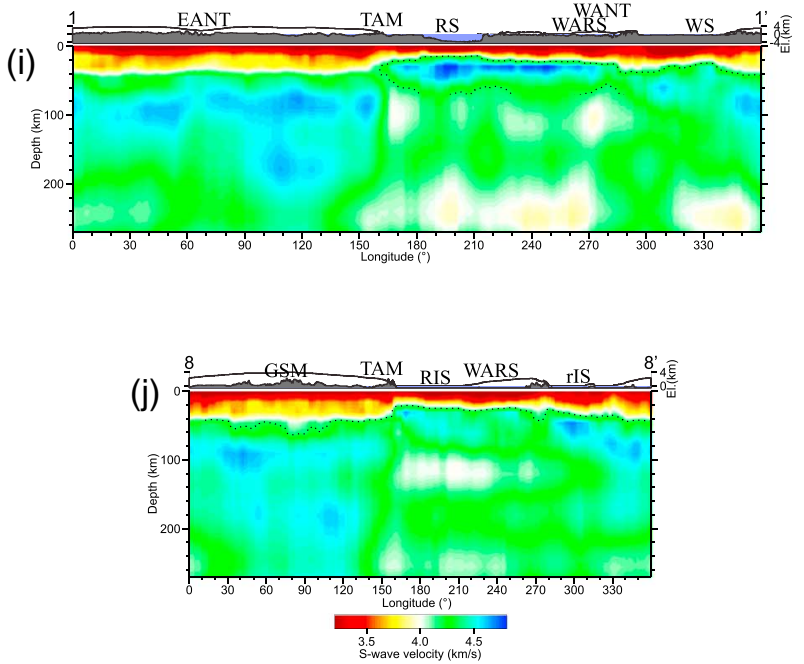

Figure 7. (continued)

with the isovelocity contour from surface waves, we note that they, in part, measure different features: the results from receiver function analysis only represent the local structure beneath the station, however, those from surface wave inversions, as in our model, average information over a large lateral area.

Transect A-A' (Figure 7a) covers the Chinese traverse from Dome A to Zhongshan station (ZhS) (inset map in Figure 7) and not only crosses the South Pole and the central regions of WANT (e.g., WARS) and EANT (e.g., GSM) but also a range of oceanic tectonic areas (e.g., normal oceanic lithosphere, the submarine plateau of Kerguelen large igneous province, and mid-ocean ridges) as well as volcanoes in WANT and the St. Paul-Amsterdam hot spot (STP). This transect is the most extensive across the Antarctic Plate. The $4.2 \mathrm{~km} / \mathrm{s}$ isovelocity contour beneath five stations (CHNB, EAGLE, DT154, Zhongshan, and DAVI) to the north of the GSM is shallower than the Moho depths in AN-Moho. The five stations are located near the border of Princess Elizabeth Land and close to the Lambert Graben valley. The inconsistency of the isovelocity contour with Moho depths for these stations indicates that the crustal structure beneath this region may be different as compared with other regions of continental Antarctica and therefore requires a higher velocity definition of the Moho beneath this region. Apart from these five stations, the contour line is consistent with the Moho positions from AN-Moho, including the shallow Moho beneath WANT and the deep Moho just beneath the GSM. The consistency indicates that a $4.2 \mathrm{~km} / \mathrm{s}$ contour defines Moho topography for at least most of the continental region. In the oceanic region of the transect, although the resolution of our model is low, the model still shows some details of Moho variations, such as thicker crust just beneath the Kerguelen submarine plateau (KP) than in the other oceanic regions. At the depths of $80-250 \mathrm{~km}, \mathrm{~S}$ velocities beneath East Antarctica is higher than other regions, indicating that the base of seismic lid beneath EANT, particularly beneath the GSM, can be at the depths of $>200 \mathrm{~km}$.

In addition to also crossing a mid-ocean ridge, oceanic lithosphere, and EANT, transect B-B' is a representative transect crossing the TAM and WARS of WANT. The contour is abruptly too deep at two positions labeled "U" in the figure. At the two positions, a velocity of $4.2 \mathrm{~km} / \mathrm{s}$ may be too high to represent the Moho, which 


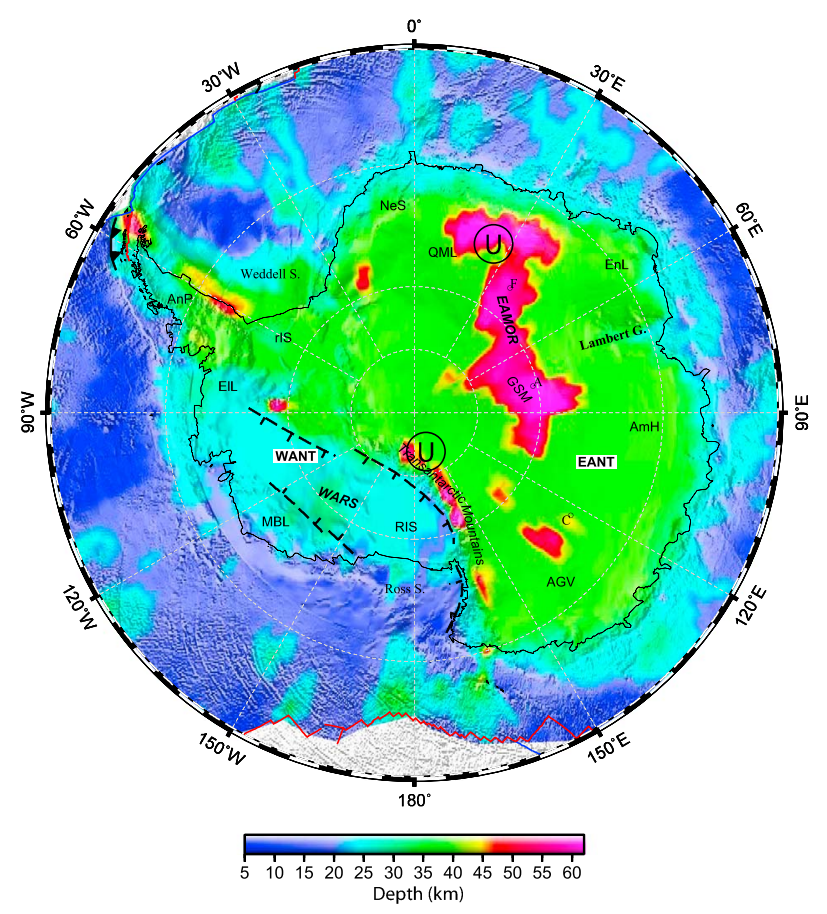

Figure 8. Depth map of isovelocity contours for $S$ velocity at $4.2 \mathrm{~km} / \mathrm{s}$. The circles labeled with $U$ mark the positions that the $4.2 \mathrm{~km} / \mathrm{s}$ isovelocity contour is too deep. implies a lower velocity at the Moho at these two positions. The $4.2 \mathrm{~km} / \mathrm{s}$ isovelocity contour (Figure $7 \mathrm{~b}$ ) closely coincides with the Moho beneath the station in WARS.

Transect $L-L^{\prime}$ is along the station arrays of GAMSEIS and TAMSEIS and should have highest resolution at positions beneath the stations. Transect $M-M^{\prime}$ is nearly parallel to and along a similar region as L-L'. Transect N-N' crosses EANT and, notably, Dome A in the GSM and Dome C. Crust that is markedly thicker than neighboring areas is found beneath Dome $A$ in the GSM in transects $L^{-} L^{\prime}$ and $\mathrm{N}-\mathrm{N}^{\prime}$. The $4.2 \mathrm{~km} / \mathrm{s}$ isovelocity contour line of transects L-L', M-M', and N-N' (Figures $7 \mathrm{e}-7 \mathrm{~g}$ ) is consistent with the position of the Moho discontinuity in AN-Moho beneath most of the seismic stations. In transects $\mathrm{M}-\mathrm{M}^{\prime}$ and $\mathrm{N}-\mathrm{N}^{\prime}$, the isovelocity contour at a position labeled $U$ abruptly deepens, which requires a lower Moho velocity just at the positions.

In summary, the above figures provide good definition of the lithosphere and asthenosphere beneath Antarctica. EANT has a thick crust and lithosphere, with the thickest crust probably beneath the GSM, but the thickest lithosphere $(>200 \mathrm{~km}$ ) most likely occurs between Dome $A$ and Dome $C$. The oceanic region has thinnest crust and lithosphere. WANT has an intermediate crust and lithosphere between EANT and oceanic region. Furthermore, the $4.2 \mathrm{~km} / \mathrm{s}$ isovelocity contour line closely coincides with the Moho discontinuity from most data in AN-Moho, including beneath intracontinental seismic stations and some stations close to the

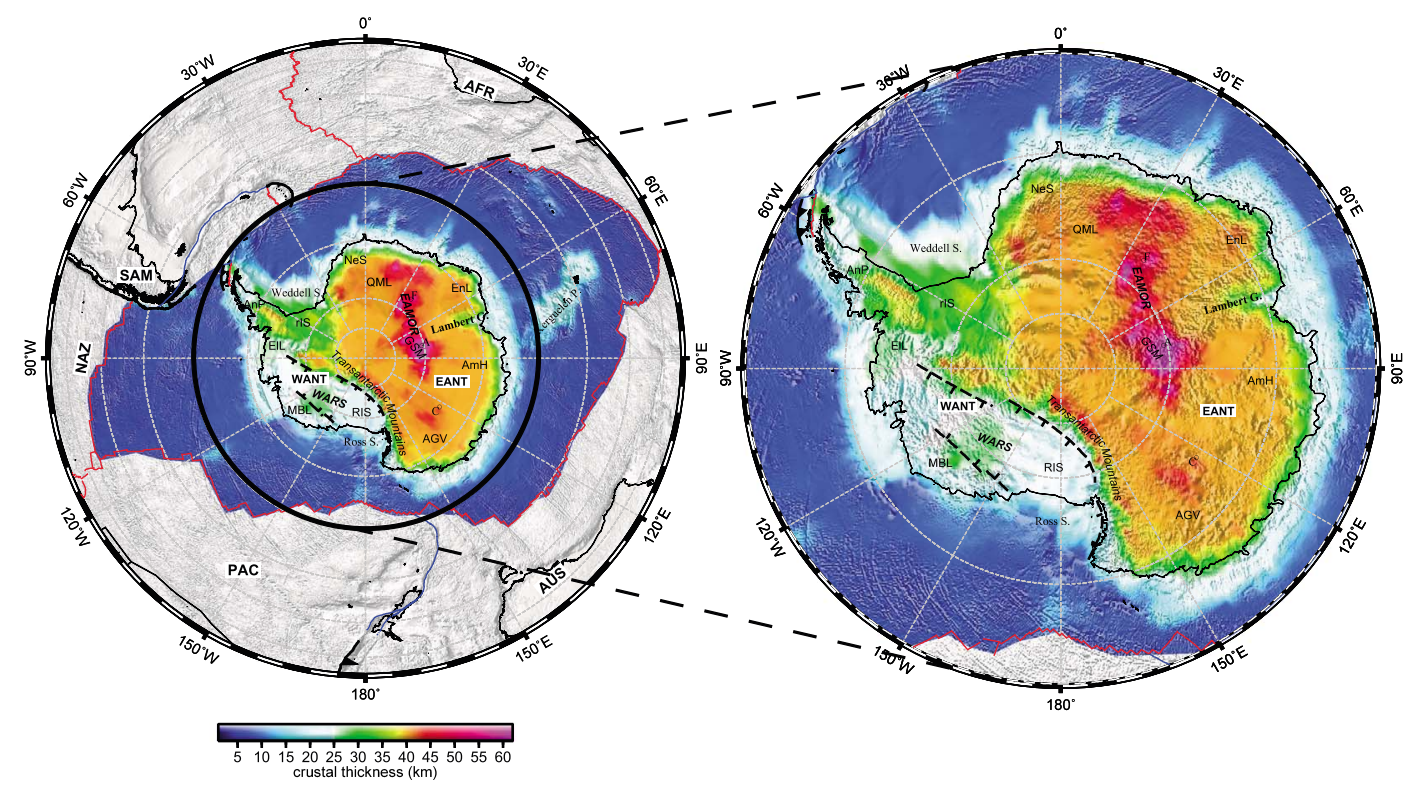

Figure 9. Crustal thickness (Moho discontinuity) map of the Antarctic Plate. The symbols are the same as those in Figure 1. 
a)
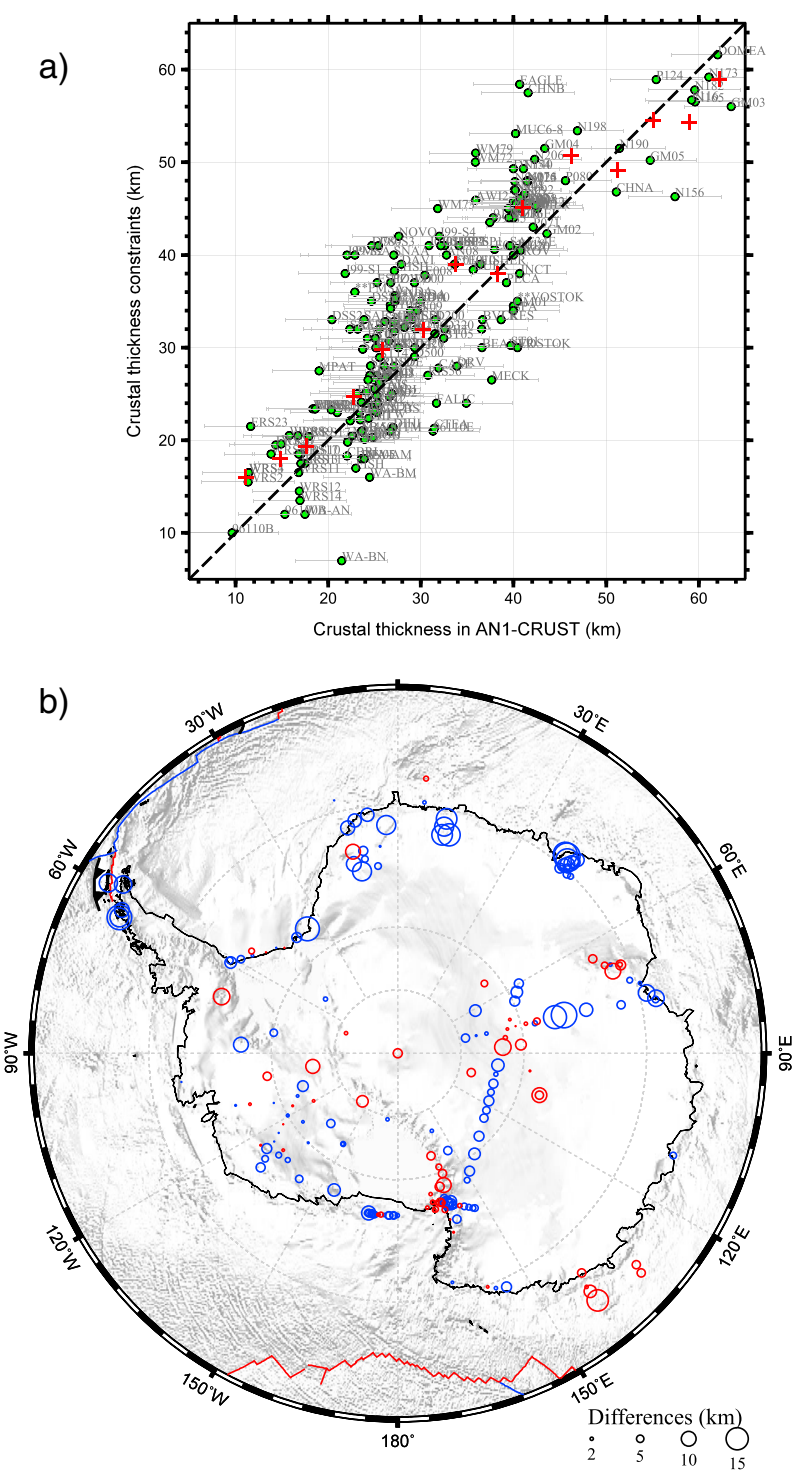

Figure 10. Relationship between crustal thicknesses in AN1-CRUST, derived from 3-D S-velocity model of AN1-S, and the constraints in AN-Moho, from previous studies. (a) The error bars represent the uncertainty $(5 \mathrm{~km})$ for each Moho point because of the $5 \mathrm{~km}$ layer thickness in our 3-D S-velocity model around the Moho. The red plus symbols are the average crustal thickness in AN1-CRUST in each interval of $4 \mathrm{~km}$. (b) The plate shows the geographical distribution of the differences (circles) between the two data sets illustrated in Figure 10a. The blue circles indicate where the thickness in AN-Moho is more than that of AN1-CRUST, whereas the red circles indicate where the opposite is the case. continent-ocean transition zone. This indicates that the Moho discontinuity topography can be depicted by the isovelocity contour obtained from our 3-D $S$-velocity model in most areas.

\subsection{Moho Topography}

\subsubsection{Construction of AN1-CRUST}

Our S-velocity transects indicate that the $4.2 \mathrm{~km} / \mathrm{s}$ isovelocity contour corresponds with most of the Moho depths estimated from previous body wave studies. The $4.2 \mathrm{~km} / \mathrm{s} S$-velocity contour topography is shown in Figure 8. However, as described above, at areas marked with circles labeled $U$ in Figure 8 and in vertical transects $M-M^{\prime}$, $\mathrm{N}-\mathrm{N}^{\prime}$, and B-B' (Figure 7), the S-velocity contour of $4.2 \mathrm{~km} / \mathrm{s}$ is unusually deep. These areas have a lower velocity at the top of the upper mantle relative to neighboring regions. Therefore, the velocity at the Moho is somewhat variable throughout Antarctica.

In order to evaluate the $S$ velocities in the vicinity of the Moho $\left(V_{\text {Moho }}\right)$, we retrieved $S$ velocities at all the Moho depths in the compilation of AN-Moho from our $S$-velocity model, AN1-S. The mean of all the $S$ velocities at the Moho is $4.21 \mathrm{~km} / \mathrm{s}$ with a standard deviation of $0.28 \mathrm{~km} / \mathrm{s}$. This confirms the correspondence of the position with an $S$ velocity of $4.2 \mathrm{~km} / \mathrm{s}$ to almost the Moho depths but also indicates that $V_{\text {Moho }}$ is not fixed but has significant variability.

Using equation ( 3 ) and considering the range of $S$ velocities, which are possible at the Moho described above, we retrieved a map of the Moho topography (or crustal thickness) from our 3-D seismic model, which we denote as AN1-CRUST (Figure 9). Given that Rayleigh waves with an average period of $50 \mathrm{~s}$ can resolve the structure down to $\sim 50 \mathrm{~km}$ and that the Moho depth of the Antarctic Plate is less than $65 \mathrm{~km}$

everywhere, the resolution map of $50 \mathrm{~s}$ shown in Figure S3c in the supporting information indicatively represents the lateral resolution length of the Moho topography.

The correlation between the Moho depths in AN1-CRUST and AN-Moho are shown in Figure 10a, and the geographical distribution of the differences between the two data sets is shown in Figure 10b. A good correlation generally exists between the average Moho depths (red plus symbols in Figure 10a) from AN1-CRUST and AN-Moho, mostly in Antarctic continent. Besides in the continent, the Moho depths in the oceanic region (Figure 9) determined from AN1-S using equation (3) are still reasonable, which demonstrates that the definition of the Moho position in equation (3) can be simultaneously used in various regions. Most 
of the points with a large difference between the two data sets are near tectonic transition zones, such as continent-ocean transitions (Figure 10b), where complex and large lateral variations in Moho topography may occur over short distances that are not resolvable with our model.

\subsubsection{Main Features of the Antarctic Crustal Thickness Map}

The TAM divides Antarctica into two blocks (EANT and WANT) with distinctly different crustal thicknesses. The whole of EANT has crust thicker than $40 \mathrm{~km}$, and the thickest crust $(\sim 61 \mathrm{~km})$ in Antarctica is located just beneath Dome A, at the center of the GSM. The areas close to QML and Dome F, where no reliable information on the crust was previously available, also has thick crust similar to that of the GSM. Therefore, the topographic highs of the EANT Mountain Ranges (EAMOR or called EANT Highlands) from QML to Dome $F$ and then to the GSM (Figure 1) are all underlain by thick crust (zoom-in inset of Figure 9). The Lambert Graben area, including the Amery ice shelf, has relatively thin crust, which is another pronounced feature of EANT.

In WANT, the southern boundary, close to the regions form TAM to Ellsworth Land (EIL), of the WARS separates WANT into two blocks with markedly different crustal thicknesses. The crust beneath the WARS is thin, and the Ross Sea area beneath the Ross ice shelf (RIS) has the thinnest crust in Antarctica (Figures 7j and 9). The crust is somewhat thicker in Marie Byrd Land and along the East (Siple) coast of the Ross Sea. Most of the other regions in WANT, including the Ronne ice shelf (rIS), have similar crustal thicknesses that are more than $30 \mathrm{~km}$. Interestingly, the northern tip of the Antarctic Peninsula has crust that is thicker than in surrounding areas, which will be discussed in M. An et al. (manuscript in preparation, 2014).

As we expected, the oceanic crust is generally thin, except for a thicker crust just beneath the Kerguelen submarine plateau. However, we note that the resolution of our model in the oceanic region is poor.

\section{Discussion}

\subsection{Comparison of AN1-CRUST With Other Recent Models}

The oceanic crust is generally thin $(<10 \mathrm{~km})$ and has small thickness variations [McClain and Atallah, 1986; Chen, 1992; White et al., 1992], with the exception of overthickened oceanic crust (10-35 km) beneath oceanic plateaus [Kerr, 2003], such as the Kerguelen Plateau ( 22 km) [Operto and Charvis, 1996]. Even though our model has poor resolution in oceanic regions (Figure S3C in the supporting information), our model of AN1-CRUST (Figure 9) agrees with previous studies, showing that oceanic crust is generally thin except for a thicker crust just beneath the Kerguelen submarine plateau.

The crustal thicknesses in WANT are well studied by seismic receiver functions [Chaput et al., 2014]. A marked feature in the results is crustal thickening beneath the Marie Byrd Land (MBL) volcanic province and the Ellsworth Whitmore Mountains [Chaput et al., 2014]. The thicknesses beneath the seismic stations in Chaput et al. [2014] were used as constraints (Figure 4) in our S-velocity inversion. Even though the influence on the $S$ velocities in regions near a position with a Moho constraint is insignificant, it is worth noting that our Moho depth model also resolves crustal thickening beneath the MBL volcanic province.

The Moho topography beneath the Antarctic continent has also been studied from gravity observations [Llubes et al., 2003; Block et al., 2009; von Frese et al., 2009; O'Donnell and Nyblade, 2014]. However, constraints from seismic studies are important to constrain the absolute Moho depths obtained using gravity observations, as these are not well resolved in gravity inversions. The most recent study [O'Donnell and Nyblade, 2014] used seismic measurements similar to those listed in AN-Moho (Figure 4) and used most recent global gravity field model based on a combination of Gravity Field and Steady-State Ocean Circulation Explorer, Gravity Recovery and Climate Experiment, CHAllenging Minisatellite Payload, and satellite laser ranging data. The resulted crust thickness variation pattern in O'Donnell and Nyblade [2014] is generally similar to our crustal thickness model, AN1-CRUST. However, the absolute crustal thicknesses at some positions are different in AN1-CRUST. For example, the thickest crust in O'Donnell and Nyblade [2014] is $\sim 50 \mathrm{~km}$ at the GSM, at which our model shows $\sim 60 \mathrm{~km}$, which is closer to that in previous receiver function studies [Hansen et al., 2010; Feng et al., 2014] (Figure 4). In summary, we are able to present a generalized Moho topography model which improves on previous broad scale models.

\subsection{Isostatic Equilibrium of Antarctica}

A comparison of the crustal thicknesses in Figure 9 with the surface topography in Figure 1 shows that the Moho discontinuity topography beneath EANT is approximately inversely proportional to the surface 


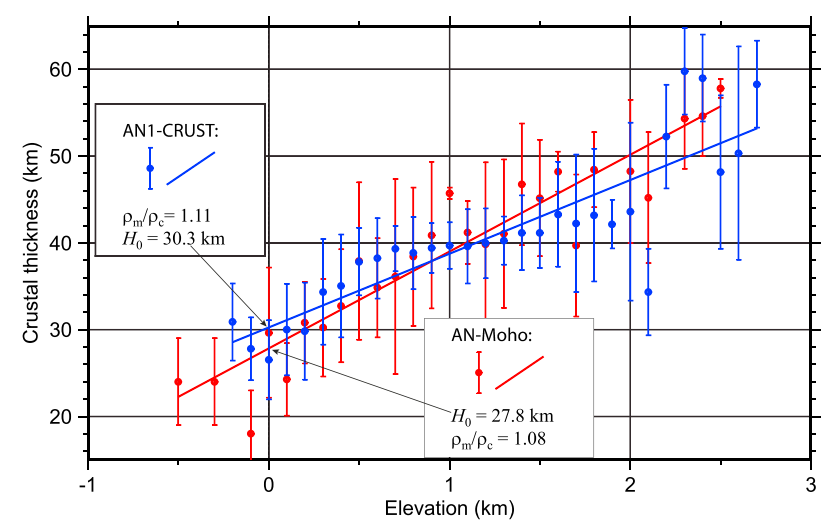

Figure 11. Crustal thickness as a function of surface elevations. The elevation at any point in this figure was corrected for ice and water layers by adding an equivalent rock thickness with the same mass as the ice and water to the rock surface. The densities of water, ice, and rock used in the conversion are $1,0.92$, and $2.8 \mathrm{Mg} / \mathrm{m}^{3}$, respectively. The lines are linear fits of crustal thicknesses and elevations. The surface elevation data were taken from ETOPO2, and the ice thickness data were taken from Bedmap2 [Fretwell et al., 2013]. topography. For example, the highlands of the EAMOR region corresponds to a negative depression of the Moho discontinuity and, beneath the highest point (Dome $A$ of the GSM), the Moho discontinuity is at its deepest point. This relationship indicates that East Antarctica is largely isostatically compensated according to an Airy isostasy model. 5.2.1. Crustal Density-Thickness Relationships From an Airy Isostasy Model

According to the Airy-Heiskanen isostasy model [Airy, 1855; Heiskanen, 1931], crustal thickness can be assumed to have a linear relationship with surface elevation, for assumed average crustal $\left(\rho_{\mathrm{c}}\right)$ and upper mantle $\left(\rho_{\mathrm{m}}\right)$ densities. If water of thickness $\left(h_{w}\right)\left(\rho_{w}=1.0 \mathrm{Mg} / \mathrm{m}^{3}\right)$ and ice of thickness ( $\left.h_{i}\right)\left(\rho_{i}=0.92 \mathrm{Mg} / \mathrm{m}^{3}\right)$ are also considered,

then the surface topography will be the sum of $h_{i}, h_{w}$, and the rock surface elevation. After surface elevation is corrected by converting $h_{i}$ and $h_{w}$ to equivalent rock thicknesses, the Airy isostasy model is represented by the linear relationship between corrected surface elevation $\left(h_{c}\right)$ and crustal thickness $(H)$ as follows:

$$
H=H_{0}+\frac{\rho_{c}}{\rho_{m}-\rho_{c}} h_{c}=H_{0}+\frac{1}{\rho_{m} / \rho_{c}-1} h_{c}
$$

where $H_{0}$ is a constant representing zero-elevation crustal thickness. If two more groups of $H$ and $h_{c}$ are known, $H_{0}$ and $\rho_{m} / \rho_{c}$ can be estimated from equation (4).

Using AN1-CRUST and AN-Moho, crustal thicknesses as a function of topographic elevations for the Antarctic continent are shown in Figure 11. The parameters $H_{0}$ (vertical intercept) and $\rho_{m} / \rho_{c}$ (related with slop) for the linear relationship (equation (4)) are marked in the figure. The linear relationship of Antarctica is very different with that in the average of other continents, as demonstrated below.

In global continental areas with a crustal thickness of $>30 \mathrm{~km}$, the topography at $0 \mathrm{~km}$ is found to correspond to a zero-elevation crustal thickness $\left(H_{0}\right)$ of $40 \mathrm{~km}$ [Watts, 2007], based on the Airy model and using the global crustal model of CRUST2.0 [Bassin et al., 2000]. However, for Antarctica, if only using the crustal thicknesses from AN-Moho, then $H_{0}$ is $\sim 28 \mathrm{~km}$ (Figure 11), and all crustal thicknesses from AN1-CRUST in the Antarctic continent give a value of $H_{0}$ of $\sim 30 \mathrm{~km}$. Similar result can be found if only the regions with a crustal thickness of $>30 \mathrm{~km}$ in the Antarctic continent are considered (Figure 11). Thus, the $H_{0}(\sim 30)$ for Antarctica is markedly smaller that for the global average $(40 \mathrm{~km})$.

\subsubsection{Densities Inferred From Airy Isostasy}

The average oceanic crustal density is $2.89-3.00 \mathrm{Mg} / \mathrm{m}^{3}$ [Carlson and Raskin, 1984], and the average continental crust density is $2.83 \mathrm{Mg} / \mathrm{m}^{3}$ [Christensen and Mooney, 1995]. Using $\rho_{m}=3.30 \mathrm{Mg} / \mathrm{m}^{3}$ suggested by Wang [1970] and considering the ratios $\left(\rho_{m} / \rho_{c}\right)$ (Figure 11) from AN-Moho and AN1-CRUST, the estimated average crustal densities for the Antarctic continent would be $\sim 3.0$ and $\sim 2.94 \mathrm{Mg} / \mathrm{m}^{3}$. These calculated average crustal densities are close to the upper range of average oceanic crust and are $\sim 0.1 \mathrm{Mg} / \mathrm{m}^{3}$ higher than the typical density $\left(2.83 \mathrm{Mg} / \mathrm{m}^{3}\right)$ of continental crust. In general, if a thermal expansion value of $3.0 \times 10^{-5} \mathrm{~K}^{-1}$ for the crust is used, a $100^{\circ}$ temperature variation can cause a $\sim 0.01 \mathrm{Mg} / \mathrm{m}^{3}$ density variation for a mineral with a density of $2.9 \mathrm{Mg} / \mathrm{m}^{3}$ [Tassara, 2006]. Therefore, a density increase of $0.1 \mathrm{Mg} / \mathrm{m}^{3}$ requires a temperature drop of $\sim 1000^{\circ}$, which is unrealistically large to explain the above calculated average crustal densities for the Antarctic. Therefore, the density ratios $\left(\rho_{m} / \rho_{c}\right)$ given by linear relationship (Figure 11$)$ are anomalously small.

Another possibility which results in the anomalous low density ratio is that the mantle density $\rho_{m}$ is much smaller than $3.30 \mathrm{Mg} / \mathrm{m}^{3}$ that we used. In general, the density in subcontinental lithospheric mantle (SCLM) 

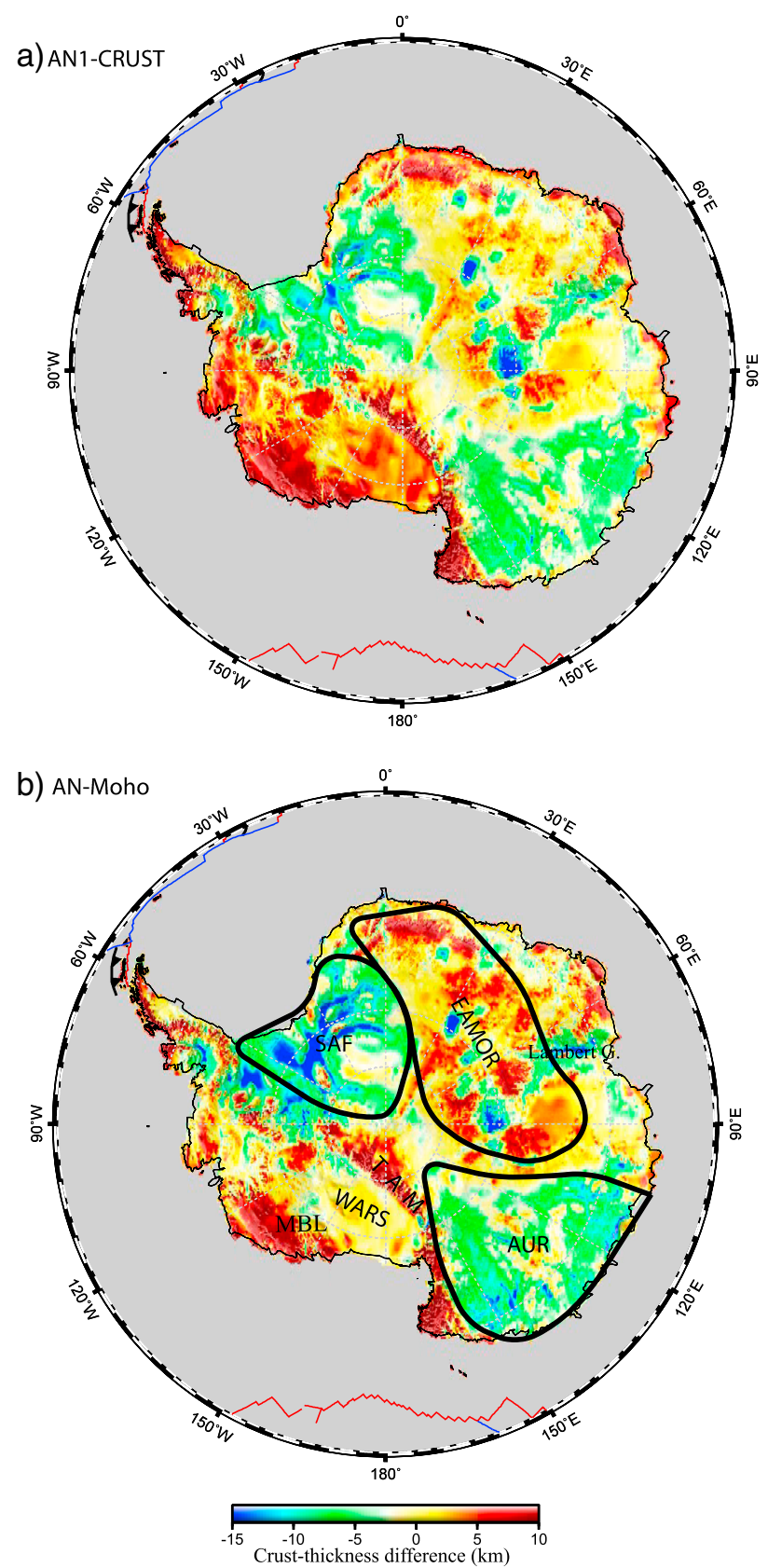

Figure 12. Differences in crustal thicknesses estimated from corrected rock elevation data from the (a) AN1-CRUST and (b) AN-Moho models. The elevation correction is the same as that in Figure 11. Small difference values may correspond to a small ratio of densities of SCLM and crust, as explained in the text. in Figure 12 can be taken to represent relative anomalies in the density ratio between SCLM and crust. A small density ratio can be due either to a low SCLM density or a high average crustal density.

Long-wavelength ( $>500 \mathrm{~km}$ ) topography of the Earth's surface is generally due to variations in crustal thickness in combination with the large-density contrast between crust and mantle [Cazenave, 1995; Turcotte and Schubert, 2002]. Therefore, we focus on the large-scale anomalies in Figure 12. From the anomaly patterns in the two maps (Figures 12a and 12b), Antarctica can be divided into several regions, as below.

may be related with its age (e.g., in Archean $\left(3.31 \pm 0.016 \mathrm{Mg} / \mathrm{m}^{3}\right)<$ Proterozoic $\left(3.35 \pm 0.02 \mathrm{Mg} / \mathrm{m}^{3}\right)<$ Phanerozoic $\left(3.36 \pm 0.02 \mathrm{Mg} / \mathrm{m}^{3}\right)$ )[Poudjom Djomani et al., 2001]. The lithospheric mantle density of $<3.30 \mathrm{Mg} / \mathrm{m}^{3}$ in the Antarctic is equal to the lower bound in the density of Archean lithosphere elsewhere in the world, indicating that Antarctica is made up of a high percentage of old lithosphere, and the SCLM in Antarctica is significantly buoyant, relative to other continents. Finally, it is possible that the Antarctic $H_{0}$ and inferred density ratio are affected by anomalous dynamic support from deep in the mantle, as has been suggested by O'Donnell and Nyblade [2014]. In this paper we evaluate possible explanations in terms of upper mantle and crustal processes.

Using the linear relationship between surface elevation and crustal thickness (Figure 11), we estimate the crustal thicknesses based on the Airy isostasy model from present-day surface elevations, and then calculate the difference $\left(\Delta H=H_{\text {iso }}-H_{\text {seism }}\right)$ between the isostasy predicted $\left(H_{\text {iso }}\right)$ and seismically constrained crustal thicknesses $\left(H_{\text {seism }}\right)$, see Figure 12. A negative crustal thickness difference value $(\Delta H)$ signifies that the real crust thickness, seismically derived crustal thickness $\left(H_{\text {seism }}\right)$, is larger than that $\left(H_{\text {iso }}\right)$ of the elevation-based isostasy, and requires a higher surface elevation than that of present day, or indicates a smaller density ratio $\left(\rho_{m} / \rho_{c}\right)$ than we used to create the map (Figure 12), from equation (4). In contrast, a positive $\Delta H$ may imply that the real crust thickness requires a bigger density ratio. These indications tell us that the real density ratios in the regions with a negative $\Delta H$ should be smaller than in the regions with a positive $\Delta H$ or say, small $\Delta H$ corresponds to a small density ratio. In this case, the values of $\Delta H$ 
Three large regions (Figure 12b) have negative values of $\Delta H$ : the block labeled by "SAF" that was once connected with the South American and African continents, which is located from $20^{\circ} \mathrm{W}$ to $60^{\circ} \mathrm{W}$ and includes the Weddell Sea and Ronne ice shelf; the block labeled by "AUR," that was once connected with the Australian continent, located from $100^{\circ} \mathrm{E}$ to $155^{\circ} \mathrm{E}$; and the Lambert Graben region which is a Permian Rift. These negative values correspond to relatively high average crustal density or low SCLM density. Given that Antarctica generally has a smaller $\rho_{m} / \rho_{c}$ than other continents, as shown above, the negative anomaly of these regions is an unusual feature. Archean rocks found in George V Land $\left(142^{\circ} 02^{\prime} \mathrm{E}-153^{\circ} 45^{\prime} \mathrm{E}\right)$ and Terre Adélie $\left(136^{\circ} \mathrm{E}-142^{\circ} \mathrm{E}\right)$ of AUR [Fanning et al., 1988; Flöttmann and Oliver, 1994; Boger, 2011] suggest that the lithosphere of the AUR block is Archean and the SCLM is lighter and more bouyant.

The SAF region and Lambert Graben also show negative values (Figure 12); however, the values cannot be attributed to low SCLM density or old SCLM because these regions are not as old as AUR blocks and even younger than EAMOR. The negative values in SAF and the Lambert Graben may imply a high density of the cooled crust which was intruded by mafic melts associated with magmatism during rifting in Permian [Harrowfield et al., 2005].

The positive values of $\Delta H$ in WARS (Figure 12a) may be due to thermal effects. The WARS is a major active continental rift associated with late Oligocene to recent volcanic activity [Behrendt et al., 1991], and thermal isostasy may affect some continental regions such as continental rifts, back arcs, and regions characterized by extensive volcanism [Hasterok and Chapman, 2007]. Besides, most of the mountain ranges have positive anomalies (Figure 12b), such as the TAM and EAMOR (e.g., the mountains close to and north of Dome F). The positive anomaly beneath the TAM may reflect Cenozoic thermal or other dynamic effects [ten Brink et al., 1997; Hamilton et al., 2001; Studinger et al., 2004; Bialas et al., 2007; Faure and Mensing, 2010]; e.g., asthenosphere upwelling and intrusion into SCLM can result in the increase of upper mantle density and the increase of crustal temperature which can resulted in the decrease of crustal density. However, in EAMOR, the anomaly cannot be attributed to Cenozoic tectonism, as no such activity has taken place since the Cambrian.

\subsection{Do the EAMOR Represent a Gondwanan Suture?}

Obscured beneath a thick ice cap, the elevated $(>3 \mathrm{~km}$ ) and rugged relief of the GSM, part of EAMOR, has long been considered enigmatic and was key research target as part of the Fourth IPY. Recent measurements [e.g., Hansen et al., 2010; Heeszel et al., 2013; Feng et al., 2014] and this study have found a very thick crust ( $\sim 60 \mathrm{~km}$ ) beneath the GSM, the topographic high of Antarctica. In the upmost upper mantle, similar to that found in the GSM by previous Rayleigh wave study [Heeszel et al., 2013], our results showed that the continental seismic lithosphere of the GSM extends deeper than $200 \mathrm{~km}$. Temperature analyses in a later paper of M. An et al. (manuscript in preparation, 2014) demonstrated that thermal lithosphere beneath the GSM is also $>200 \mathrm{~km}$ thick. Therefore, the striking features of the GSM are its high elevation, very thick crust $(\sim 60 \mathrm{~km})$, and lithosphere $(>200 \mathrm{~km})$. This study shows that similar features of thick crust and lithosphere extend across the entire EAMOR region. Given these similarities, the crusts beneath the EAMOR should be formed with similar tectonic events and in the similar time.

Within the framework of global tectonic evolution, several models have been proposed to explain the formation of the GSM. Thermal effects can generate topographic highs. It has been suggested that the GSM resulted from a Cenozoic (approximately $<50 \mathrm{Ma}$ ) mantle plume [Sleep, 2006], but no physical evidence exists to support this hypothesis. More recently, Late Permian rifting ( $250 \mathrm{Ma})$ occurs in a neighboring region has been suggested as the trigger for uplift of the GSM [Ferraccioli et al., 2011]. Late Permian rifting would have thinned and disrupted the East Antarctic continental lithosphere, but seismic models reveal a thick, continuous high-velocity continental lithosphere beneath the GSM [Heeszel et al., 2013; Lloyd et al., 2013, and this study]. In addition, rifting thins the crust and flattens the Moho topography over a large area, such as the uniformly $35 \mathrm{~km}$ thick crust of the Kaapvaal craton in Africa resulted by remelting of the lower crust in post-Archean tectonothermal events [James et al., 2003], or the present-day felsic character of the Indian Archean crust (33-34 km thick) possibly by postformation modification of the initial mafic lower crust [Jagadeesh and Rai, 2008]. The relatively thin crust beneath the Permian rift, Lambert Graben (Figure 9) in EANT may have produced by rift, too. However, the thick and highly variable crust beneath the GSM indicates that it has suffered little modification since formation. This model cannot be extended to the rest of EAMOR. 


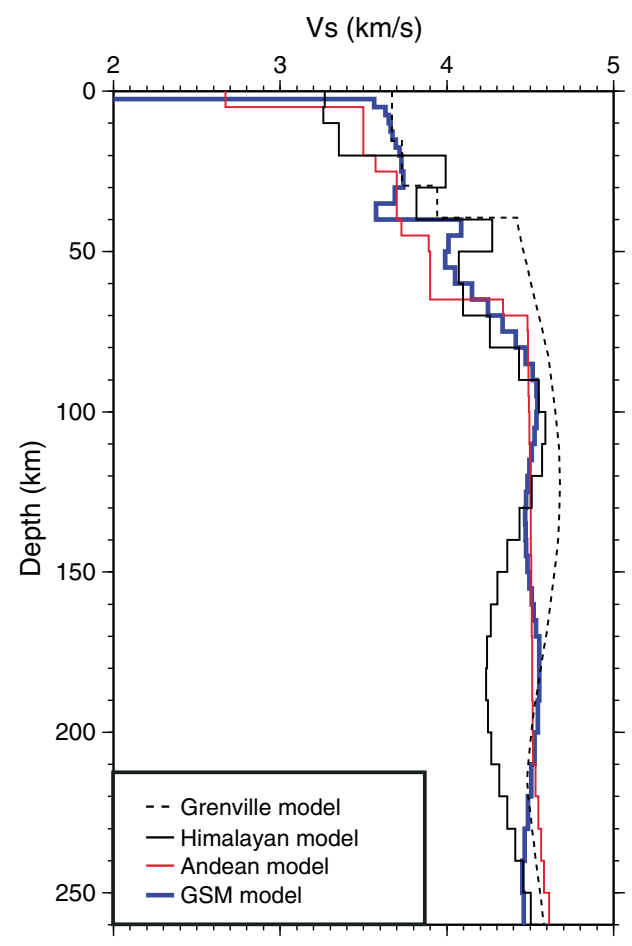

Figure 13. Comparison of $S$ velocities beneath the GSM with those in other continents. The model beneath the GSM is the same as that in Figure $5 \mathrm{a}$. The Andean model is of the $S$ velocities at the point $\left(68^{\circ} \mathrm{W}\right.$, $21^{\circ} \mathrm{S}$ ) from Feng et al. [2004], and the Himalayan model is at the point $\left(89^{\circ} \mathrm{E}, 28^{\circ} \mathrm{N}\right)$ from Feng and $A n$ [2010]. The Andean and Himalayan models were inverted from similar data (Rayleigh wave group velocities) by similar inversion methods to that for the GSM. The Grenville model is at the point $\left(76^{\circ} \mathrm{E}, 46^{\circ} \mathrm{N}\right)$ in Middle Proterozoic Grenville orogen of the North American craton inverted from Rayleigh wave group/ phase velocities by two-step ray-based tomography [Shapiro and Ritzwoller, 2002].
Globally, horizontal shortening at the present compressional orogenic regions can result in the above features (high topography, thick crust, and lithosphere) of the GSM. Fo example, the subduction of continental or oceanic plates underlying a large continent can result in both a topographic high and very thick crust in the Alpine-Himalayan mountain ranges [Hirn et al., 1984; Zhao et al., 1993; Hauck et al., 1998] and the Andes [Beck et al., 1996; Yuan et al., 2002; Assumpção et al., 2013]. The lithosphere can also thicken under compression to produce a very thick lithosphere such as in the Himalayas [An and Shi, 2006; Feng and An, 2010; Feng et al., 2010] and Andes [Feng et al., 2004, 2007].

In order to check the similarities between the lithosphere structures, we compared the $S$ velocities beneath the GSM with those of present orogenies (the Andes and the Himalayas) and a Proterozoic convergent orogeny (the Grenville) (Figure 13). The Grenville orogeny took place at 1.0-1.3 Ga [Tollo et al., 2004]. The figure shows that the S-velocity variation beneath the GSM is similar to those beneath the present orogenies down to the depth of $140 \mathrm{~km}$ (Figure 13). The Andean model matches the GSM model well throughout the profile, but the Himalayan model lacks the high-velocity lithosphere at depths greater than $150 \mathrm{~km}$. The GSM model is similar to that of the Grenville model in the crust down to $30 \mathrm{~km}$; however, marked difference can be found in the depths of 30-170 km. These similarities with present convergent orogenies confirm the viewpoint that the GSM was formed during a convergent (subduction or collision) orogeny.

It has been proposed that the GSM formed in response to late Carboniferous-Early Permian ( 300 Ma) far-field compression associated with the formation of Pangaea [Veevers, 1994; Veevers et al., 2008]. While a compressional orogen can generate a plateau or a mountain range,

such as the Tibetan Plateau or the Andes, in the near-field of the compression zone, mountain ranges are seldom generated in the far field. Studies on Detrital zircons from coastal parts of EANT show no zircons of Carboniferous age [van de Flierdt et al., 2008; Veevers and Saeed, 2011]. Consequently, it is unlikely that the GSM formed with the formation of Pangaea.

The pre-Cenozoic orogenic belts in EANT developed during four major orogenic cycles [Talarico and Kleinschmidt, 2008] spanning approximately 0.9-1.3 Ga (Grenvillian-aged orogens), 500-600 Ma (Ross and Pan-African orogens), 200-250 Ma (Ellsworth or Weddell Orogen), and 90-150 Ma (Antarctic Andean Orogen), with only the Grenvillian- and Pan-African-aged orogens occurring anywhere near the GSM. The GSM lies near the Grenvillian-aged Payner orogen and may have also formed in Grenvillian time. However, the crust of the EAMOR was distributed across several continents prior to the formation of Gondwana and cannot have formed from a Grenvillian-aged orogeny during the amalgamation of the Rodinia supercontinent. The marked difference between the GSM and Grenville S-velocity structures (Figure 13) also suggests that the GSM was not formed by a Grenvillian-aged orogen. Consequently, the GSM must have formed in response to Late Neoproterozoic ( $<700 \mathrm{Ma}$ ) or Early Paleozoic (approximately $>500 \mathrm{Ma}$ ) orogenic activities associated with the assembly of Gondwana, which is compatible with geological evidence [Zhao et al., 1995; Fitzsimons, 2000, 2003; Liu et al., 2003, 2006] found close to the continent margins of EANT. 


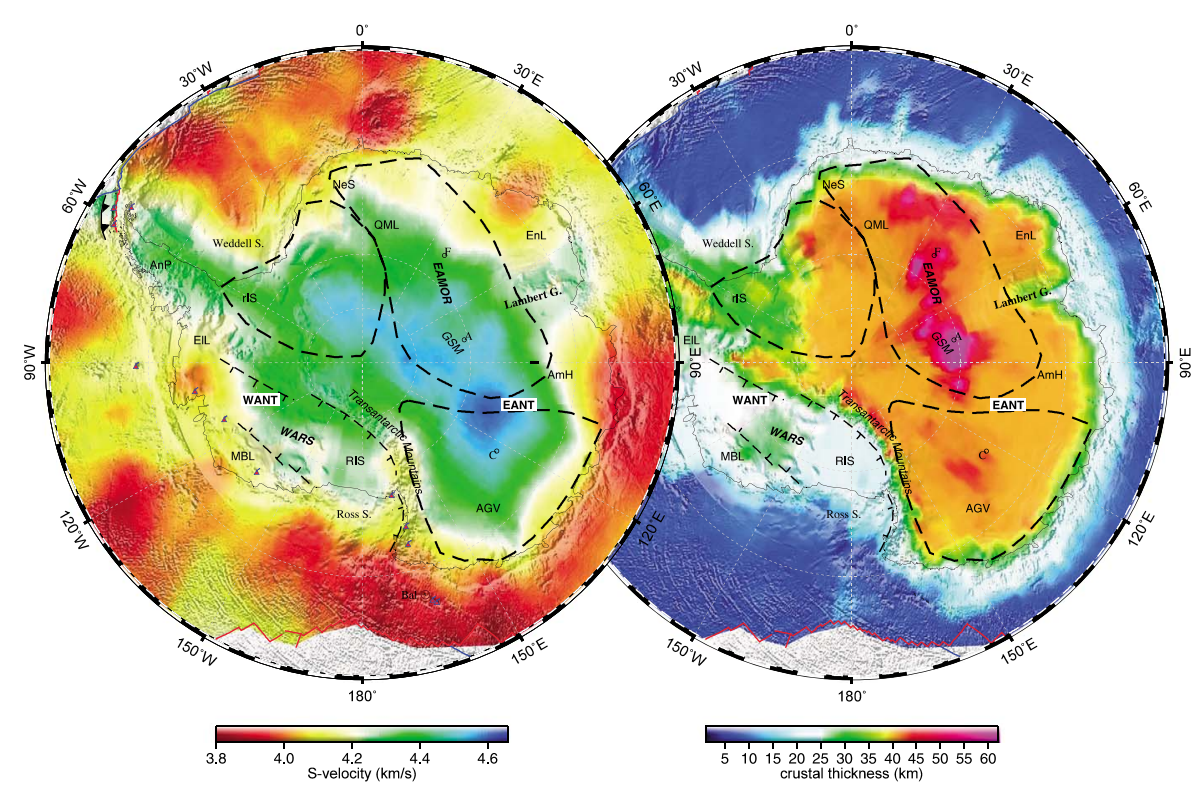

Figure 14. Comparison of interpretation with lithospheric upper mantle $S$-velocities at the depth of $200 \mathrm{~km}$ and crustal thicknesses. The former is the same as in Figure $6 \mathrm{~d}$ and the latter as in Figure 9. The symbols and labels are the same as in Figure 1 or Figure 12b.

Before $550 \mathrm{Ma}$, the GSM may have been part of East Gondwana (Figure S1 in the supporting information), which consisted of Australia and most of EANT, while the north Prince Charles Mountains and India belonged to Indo-Antarctica which amalgamated with West Gondwana prior to $550 \mathrm{Ma}$ [Boger et al., 2002; Boger, 2011]. East Gondwana amalgamated with the large continent composed of West Gondwana and Indo-Antarctica after $550 \mathrm{Ma}$ (Figure S1 in the supporting information and Figure 15b), and as such, the GSM should lie close to the suture. We observe that the S-velocity variation in the upper mantle beneath the GSM is more similar to that observed beneath the Andes than the Himalayas (Figure 5), indicating that the GSM is formed by an oceanic subduction like in the Andes. However, no oceanic plate can be found adjacent to the GSM after Gondwana amalgamated; therefore, the GSM should be intermediate orogeny between the Andes and Himalayas; i.e., the GSM formed by oceanic subduction overlying a continent and the subduction finally stopped after Gondwana supercontinent is amalgamated. Considering that the oceanic plate subduction in South American only resulted in a large mountain chains (the Andes), while the continental subduction or collision in the Himalayas produced a broad topographic high (the Tibetan Plateau), it is unlikely that a plateau like the Tibetan Plateau was formed during the Gondwanan amalgamation.

Given the similarities in crustal thicknesses and surface topography across the EAMOR, including the GSM and the mountains close to Dome F, the EAMOR may represent the convergent suture between East Gondwana and the large continent of West Gondwana and Indo-Antarctica that formed during the Pan-African orogen during 550-500 Ma, as illustrated in Figure 15. If the above processes are true, the lithosphere beneath EAMOR would be formed and transformed just during the above tectonic events, and as such, the lithosphere of EAMOR should be younger than neighboring regions. The analyses from Airy isostasy in the last subsection indicated that the lithosphere of EAMOR is younger than the Archean AUR and SAF, which supports the above hypothesis. However, a $500 \mathrm{Ma}$ age for the EAMOR lithosphere is generally incompatible with the very thick fast velocity lithosphere, which shows greatest similarity to early Proterozoic and Archean regions worldwide [Heeszel et al., 2013]. One possibility is that the Pan-African collisional orogeny that produced the GSM juxtaposed and thickened older lithosphere of the colliding terraines.

A basic issue for a subduction is to discriminate which one of the convergent blocks were the overriding and subducting blocks. Due to underlying subduction, respectively, by the Indian continent and Nazca Plate, the Tibetan Plateau and the South American continent have thick lithosphere close to the subduction zone. 
(a)

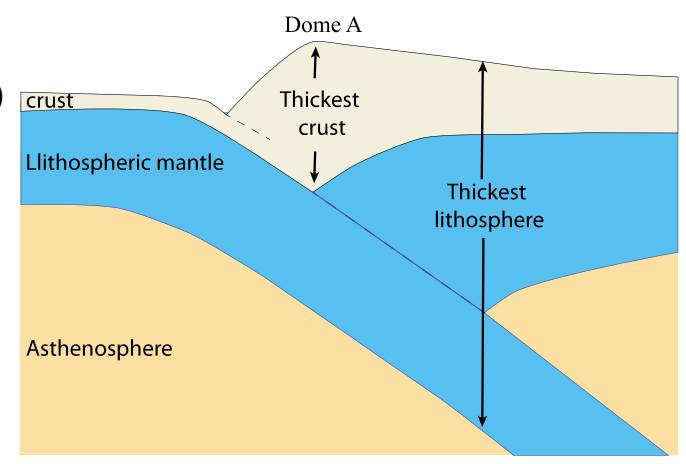

(b)

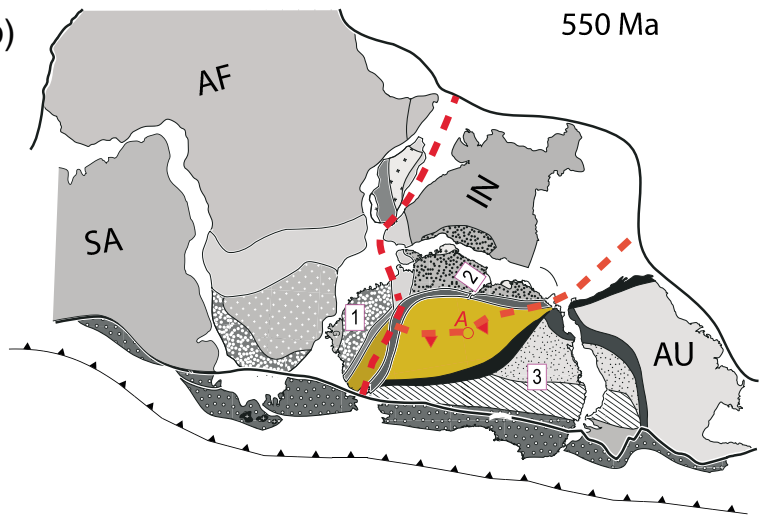

Figure 15. Illustrations of the collisional orogeny forming Gondwana. (a) The region with thickest lithosphere should be in the overriding block. (b) The amalgamation suture of Gondwana is along the EAMOR including the GSM. AF = African continent, $A U=$ Australian continent, IN = Indian continent, and $S A=$ South American continent. A red circle labeled with " $\mathrm{A}$ " marks the position of Dome A of the GSM. Three rectangles labeled with a number highlight typical areas of EANT which were, respectively, parts of three continents (1: West Gondwana, 2: Indo-Antarctica, and 3: East Gondwana). The block shaded by yellow color has not been geologically studied. The red dashes in Figure 15b mark the suture zone of the amalgamation of the three continents. The amalgamation suture crossing Dome $A$ is from this study; the others in the subfigure are simplified from Boger [2011]. the high topography could have been preserved over such a long tectonic history. Detrital apatites obtained from Eocene (33-55 Ma) sands in Prydz Bay at the terminus of the Lambert Graben, which drained a large preglacial basin including the northern Gamburtsev Mountains, indicate that erosion was very slow, averaging $0.01-0.02 \mathrm{~km} / \mathrm{Myr}$ for over $250 \mathrm{Myr}$ [Cox et al., 2010]. This very slow erosion rate supports the preservation of high topography within the interior of East Antarctica since the cessation of Permian rifting. Even though Antarctica did not remain in cold polar regions for an extended period ( $>250 \mathrm{Ma})$, the erosion rates for the EAMOR/GSM could have remained sufficiently low if the topographic high was large enough, its thermal and tectonic activity remained low, and its superficial rocks were resistant to erosion. For example, southern and central Tibet maintained low erosion rates of $<0.03 \mathrm{~km} / \mathrm{Myr}$ during 20-166 ka [Lal et al., 2004]. If the erosion rate of 0.01-0.02 km/Myr from Cox et al. [2010] continued for a period of $500 \mathrm{Myr}$, crustal thickness would have been reduced by 5-10 km. If the GSM formed 500 Myr ago with a crustal thickness of $\sim 70 \mathrm{~km}$, similar to that in the Himalayas [Hirn et al., 1984; Hauck et al., 1998] and the Andes [Beck et al., 1996; Yuan et al., 2002; Assumpção et al., 2013], the current crustal thickness ( 60 km) beneath the GSM is still reasonable. Thick crust in some ancient orogenic regions, such as the Paleozoic Southern Urals [Carbonell et al., 1996; Brown et al., 2006] and the pre-Cambrian suture zone in southern Finland [Mooney, 2007], support this hypothesis. The extreme longevity and preservation of the GSM topography by low erosion rates has also been 
suggested by Heeszel et al. [2013], who also favored the early Paleozoic formation of the GSM. In summary, with appropriately low erosion rates, the thick crust beneath the EAMOR can endure for a long time.

\section{Conclusions}

The deployment of seismographs across most of Antarctica since the Fourth IPY (2007-2008) as part of international seismological projects has enabled better lateral resolution of the continent. Using Rayleigh wave group velocities retrieved from 122 broadband seismic stations in Antarctica, we have constructed a 3-D $S$ wave velocity model of the crust and upper mantle beneath the Antarctic Plate, from which a Moho depth map for the entire Antarctic Plate was then generated. Our results show that a thick crustal belt exists from the GSM to QML along the center of the EAMOR, including in regions close to QML and Dome $F$, where no reliable information on the crust was previously available. The thickest crust in Antarctica $(\sim 61 \mathrm{~km})$ is in this belt, located just beneath the area of Dome A in the GSM. Very high velocities still can be found at the $200 \mathrm{~km}$ deep beneath parts of East Antarctica, especially the region from the GSM (Dome A) to Dome C, demonstrating that the continental lithosphere extends deeper than $200 \mathrm{~km}$. Both of the crust and the lithosphere beneath EAMOR are so thick as to be like a present orogeny, implying that an orogenic history is occurred along the whole East Antarctic mountain ranges. As such, the most possible mechanism is that the mountains of EAMOR should be collision suture between East Gondwana and the large continent of West Gondwana and Indo-Antarctica formed in Pan-African orogeny during 550-500 Ma.

The topography of the Moho discontinuity beneath EANT is inversely correlated with the surface topography. For example, the high elevations of the EANT subglacial mountains correspond to a maximum negative depression of the Moho discontinuity beneath its highest point (Dome A of the GSM). This relationship indicates that all of EANT is isostatically compensated according to an Airy isostasy model. Using the crustal thicknesses and assuming a fixed mantle density, we calculated the zero-elevation crustal thickness and average crustal density of Antarctica. The calculated zero-elevation crustal thickness for Antarctica is clearly smaller than average global values, and the estimated ratio between the mantle and the average crustal densities for Antarctica is also much smaller than average values for other continents. Unless these values are affected by dynamic support deep in the mantle, the density ratio indicates that the estimated average density of Antarctic crust is too high to be explained by temperature effects on the crust or the estimated average density of Antarctic SCLM is so low as to be equal to low-density bound of Archean lithosphere elsewhere in the world. This implies that the SCLM in much of East Antarctica is old and buoyant, and that one region, AUR, with lowest density ratios, may have been formed in the Archean.

The S-velocity model and Moho-depth map are available through http://www.seismolab.org.

\section{References}

Airy, G. B. (1855), On the computation of the effect of the attraction of mountain-masses, as disturbing the apparent astronomical latitude of stations in geodetic surveys, Philos. Trans. R. Soc. London, 145, 101-104, doi:10.1098/rstl.1855.0003.

An, M. (2012), A simple method for determining the spatial resolution of a general inverse problem, Geophys. J. Int., 191, 849-864, doi:10.1111/j.1365-246X.2012.05661.X.

An, M., and M. S. Assumpção (2005), Effect of lateral variation and model parameterization on surface wave dispersion inversion to estimate the average shallow structure in the Paraná Basin, J. Seismol., 9, 449-462.

An, M., and M. S. Assumpção (2006), Crustal and upper mantle structure in intracratonic Paraná Basin, SE Brazil, from surface wave dispersion using genetic algorithm, J. South Am. Earth Sci., 21, 173-184, doi:10.1016/j.jsames.2006.03.001.

An, M., and Y. Shi (2006), Lithospheric thickness of the Chinese continent, Phys. Earth Planet. Inter., 159, $257-266$.

An, M., and Y. Shi (2007), 3-D crustal and upper-mantle temperature of the Chinese continent, Sci. China, Ser. D Earth Sci., 50, $1441-1451$.

An, M., D. Wiens, C. An, G. Shi, Y. Zhao, and Y. Li (2014), Antarctic ice velocities from GPS locations logged by seismic stations, Antarctic Sci., doi:10.1017/S0954102014000704.

Artemieva, I. M., and W. D. Mooney (2001), Thermal thickness and evolution of Precambrian lithosphere: A global study, J. Geophys. Res., 106, 16,387-16,414, doi:10.1029/2000JB900439.

Assumpção, M., M. Feng, A. Tassara, and J. Julià (2013), Models of crustal thickness for South America from seismic refraction, receiver functions, and surface wave tomography, Tectonophysics, 609, 82-96, doi:10.1016/j.tecto.2012.11.014.

Baranov, A., and A. Morelli (2013), The Moho depth map of the Antarctica region, Tectonophysics, 609, 299-313, doi:10.1016/j.tecto.2012.12.023. Bassin, C., G. Laske, and G. Masters (2000), The current limits of resolution for surface wave tomography in North America, Eos Trans. AGU, 81, F897. Bayer, B., W. H. Geissler, A. Eckstaller, and W. Jokat (2009), Seismic imaging of the crust beneath Dronning Maud Land, East Antarctica, Geophys. J. Int., 178, 860-876, doi:10.1111/j.1365-246X.2009.04196.x.

Beck, S. L., G. Zandt, S. C. Myers, T. C. Wallace, P. G. Silver, and L. Drake (1996), Crustal-thickness variations in the central Andes, Geology, 24, 407-410.

Behrendt, J. C., W. E. LeMasurier, A. K. Cooper, F. Tessensohn, A. Tréhu, and D. Damaske (1991), Geophysical studies of the West Antarctic rift system, Tectonics, 10, 1257-1273, doi:10.1029/91TC00868. 
Bell, R. E. (2008), Antarctic Earth System Science in the International Polar Year 2007-2008, in Antarctica: A Keystone in a Changing World-Online Proceedings of the 10th International Symposium on Antarctic Earth Sciences, edited by A. K. Cooper et al., pp. kp02, The Nat. Acad. Press, Washington, D. C.

Bialas, R. W., W. R. Buck, M. Studinger, and P. G. Fitzgerald (2007), Plateau collapse model for the Transantarctic Mountains-West Antarctic rift system: Insights from numerical experiments, Geology, 35, 687-690, doi:10.1130/g23825a.1.

Block, A. E., R. E. Bell, and M. Studinger (2009), Antarctic crustal thickness from satellite gravity: Implications for the Transantarctic and Gamburtsev Subglacial Mountains, Earth Planet. Sci. Lett., 288, 194-203, doi:10.1016/j.epsl.2009.09.022.

Boger, S. D. (2011), Antarctica: Before and after Gondwana, Gondwana Res., 19, 335-371, doi:10.1016/j.gr.2010.09.003.

Boger, S. D., C. J. Carson, C. M. Fanning, J. M. Hergt, C. J. L. Wilson, and J. D. Woodhead (2002), Pan-African intraplate deformation in the northern Prince Charles Mountains, East Antarctica, Earth Planet. Sci. Lett., 195, 195-210, doi:10.1016/s0012-821x(01)00587-8.

Bouin, M.-N., and C. Vigny (2000), New constraints on Antarctic Plate motion and deformation from GPS data, J. Geophys. Res., 105, 28,279-28,293, doi:10.1029/2000JB900285.

Brown, D., P. Spadea, V. Puchkov, J. Alvarez-Marron, R. Herrington, A. P. Willner, R. Hetzel, Y. Gorozhanina, and C. Juhlin (2006), Arc-continent collision in the Southern Urals, Earth Sci. Rev., 79, 261-287, doi:10.1016/j.earscirev.2006.08.003.

Carbonell, R., A. Pérez-Estaún, J. Gallart, J. Diaz, S. Kashubin, J. Mechie, R. Stadtlander, A. Schulze, J. H. Knapp, and A. Morozov (1996), Crustal root beneath the urals: Wide-angle seismic evidence, Science, 274, 222-224, doi:10.1126/science.274.5285.222.

Carlson, R. L., and G. S. Raskin (1984), Density of the ocean crust, Nature, 311, 555-558.

Cazenave, A. (1995), Goid, topography and distribution of landforms, in Global Earth Physics: A Handbook of Physical Constants, edited by T. J. Ahrens, pp. 32-39, AGU, Washington, D. C.

Chaput, J., R. C. Aster, A. Huerta, X. Sun, A. Lloyd, D. Wiens, A. Nyblade, S. Anandakrishnan, J. P. Winberry, and T. Wilson (2014), The crustal thickness of West Antarctica, J. Geophys. Res. Solid Earth, 119, 378-395, doi:10.1002/2013JB010642.

Chen, Y. J. (1992), Oceanic crustal thickness versus spreading rate, Geophys. Res. Lett., 19, 753-756, doi:10.1029/92GL00161.

Christensen, N. I. (1996), Poisson's ratio and crustal seismology, J. Geophys. Res., 101, 3139-3156, doi:10.1029/95JB03446.

Christensen, N. I., and W. D. Mooney (1995), Seismic velocity structure and composition of the continental crust: A global view, J. Geophys. Res., 100, 9761-9788, doi:10.1029/95JB00259.

Courtillot, V., A. Davaille, J. Besse, and J. Stock (2003), Three distinct types of hotspots in the Earth's mantle, Earth Planet. Sci. Lett., 205, 295-308, doi:10.1016/s0012-821x(02)01048-8.

Cox, S. E., S. N. Thomson, P. W. Reiners, S. R. Hemming, and T. van de Flierdt (2010), Extremely low long-term erosion rates around the Gamburtsev Mountains in interior East Antarctica, Geophys. Res. Lett., 37, L22307, doi:10.1029/2010GL045106.

Danesi, S., and A. Morelli (2001), Structure of the upper mantle under the Antarctic Plate from surface wave tomography, Geophys. Res. Lett., 28, 4395-4398, doi:10.1029/2001GL013431.

Dewart, G., and M. N. Toksöz (1965), Crustal structure in East Antarctica from surface wave dispersion, Geophys. J. R. Astron. Soc., 10, 127-139, doi:10.1111/j.1365-246X.1965.tb03056.x.

Durrheim, R. J., and W. D. Mooney (1994), Evolution of the Precambrian lithosphere: Seismological and geochemical constraints, J. Geophys. Res., 99, 15,359-15,374, doi:10.1029/94JB00138.

Dziewonski, A. M., and D. L. Anderson (1981), Preliminary reference Earth model, Phys. Earth Planet. Inter., 25, $297-356$.

Dziewonski, A. M., S. Bloch, and M. Landisman (1969), A technique for analysis of transient seismic signals, Bull. Seismol. Soc. Am., 59, 427-444.

Ekström, G., J. Tromp, and E. W. F. Larson (1997), Measurements and global models of surface wave propagation, J. Geophys. Res., 102, 8137-8157, doi:10.1029/96JB03729.

Engdahl, E. R., R. D. van der Hilst, and R. Buland (1998), Global teleseismic earthquake relocation with improved travel times and procedures for detph determination, Bull. Seismol. Soc. Am., 88, 722-743.

Evison, F. F., C. E. Ingham, R. H. Orr, and J. H. L. Fort (1960), Thickness of the Earth's crust in Antarctica and the surrounding oceans, Geophys. J. R. Astron. Soc., 3, 289-306, doi:10.1111/j.1365-246X.1960.tb01704.x.

Fanning, C. M., R. B. Flint, A. J. Parker, K. R. Ludwig, and A. H. Blissett (1988), Refined Proterozoic evolution of the Gawler Craton, South Australia, through U-Pb zircon geochronology, Precambrian Res., 40-41, 363-386, doi:10.1016/0301-9268(88)90076-9.

Faure, G., and T. M. Mensing (2010), The Transantarctic Mountains: Rocks, Ice, Meteorites and Water, 804 pp., Springer, New York.

Feng, M., and M. An (2010), Lithospheric structure of the Chinese mainland determined from joint inversion of regional and teleseismic Rayleigh-wave group velocities, J. Geophys. Res., 115, B06317, doi:10.1029/2008JB005787.

Feng, M., M. S. Assumpção, and S. van der Lee (2004), Group-velocity tomography and lithospheric S-velocity structure of the South American continent, Phys. Earth Planet. Inter., 147, 315-331.

Feng, M., S. Van der Lee, and M. Assumpção (2007), Upper mantle structure of South America from joint inversion of waveforms and fundamental-mode group velocities of Rayleigh waves, J. Geophys. Res., 112, B04312, doi:10.1029/2006JB004449.

Feng, M., S. van der Lee, M. An, and Y. Zhao (2010), Lithospheric thickness, thinning, subduction, and interaction with the asthenosphere beneath China from the joint inversion of seismic S-wave train fits and Rayleigh-wave dispersion curves, Lithos, 120, 116-130, doi:10.1016/ j.lithos.2009.11.017.

Feng, M., M. An, C. An, G. Shi, Y. Zhao, Y. Li, and D. Wiens (2014), Crustal thicknesses along the traverse from Zhongshan to Dome A in Eastern Antarctica, Chin. J. Polar Res., 26, 177-185.

Ferraccioli, F., C. A. Finn, T. A. Jordan, R. E. Bell, L. M. Anderson, and D. Damaske (2011), East Antarctic rifting triggers uplift of the Gamburtsev Mountains, Nature, 479, 388-392, doi:10.1038/nature10566.

Finotello, M., A. Nyblade, J. Julia, D. Wiens, and S. Anandakrishnan (2011), Crustal $V_{p}-V_{s}$ ratios and thickness for Ross Island and the Transantarctic Mountain front, Antarctica, Geophys. J. Int., 185, 85-92, doi:10.1111/j.1365-246X.2011.04946.x.

Fischer, K. M., H. A. Ford, D. L. Abt, and C. A. Rychert (2010), The lithosphere-asthenosphere boundary, Annu. Rev. Earth Planet. Sci., 38, 551-575, doi:10.1146/annurev-earth-040809-152438.

Fitzsimons, I. C. W. (2000), A review of tectonic events in the East Antarctic shield and their implications for Gondwana and earlier supercontinents, J. Afr. Earth Sci., 31, 3-23, doi:10.1016/s0899-5362(00)00069-5.

Fitzsimons, I. C. W. (2003), Proterozoic basement provinces of southern and southwestern Australia, and their correlation with Antarctica, Geol. Soc. London Spec. Publ., 206, 93-130, doi:10.1144/gsl.sp.2003.206.01.07.

Flöttmann, T., and R. Oliver (1994), Review of Precambrian-Palaeozoic relationships at the craton margins of southeastern Australia and adjacent Antarctica, Precambrian Res., 69, 293-306, doi:10.1016/0301-9268(94)90093-0.

Fretwell, P., et al. (2013), Bedmap2: Improved ice bed, surface, and thickness datasets for Antarctica, The Cryosphere, 7, 375-393, doi:10.5194/ tc-7-375-2013. 
Goes, S., R. Govers, and P. Vacher (2000), Shallow mantle temperatures under Europe from $P$ and S wave tomography, J. Geophys. Res., 105, 11,153-11,169, doi:10.1029/1999JB900300.

Hamilton, R. J., B. P. Luyendyk, C. C. Sorlien, and L. R. Bartek (2001), Cenozoic tectonics of the Cape Roberts Rift Basin and Transantarctic Mountains Front Southwestern Ross Sea, Antarctica, Tectonics, 20, 325-342, doi:10.1029/2000TC001218.

Hansen, S. E., J. Julià, A. A. Nyblade, M. L. Pyle, D. A. Wiens, and S. Anandakrishnan (2009), Using S wave receiver functions to estimate crustal structure beneath ice sheets: An application to the Transantarctic Mountains and East Antarctic craton, Geochem. Geophys. Geosyst., 10, Q08014, doi:10.1029/2009GC002576.

Hansen, S. E., A. A. Nyblade, D. S. Heeszel, D. A. Wiens, P. Shore, and M. Kanao (2010), Crustal structure of the Gamburtsev Mountains, East Antarctica, from S-wave receiver functions and Rayleigh wave phase velocities, Earth Planet. Sci. Lett., 300, 395-401, doi:10.1016/j.epsl.2010.10.022.

Harrowfield, M., G. R. Holdgate, C. J. L. Wilson, and S. McLoughlin (2005), Tectonic significance of the Lambert graben, East Antarctica: Reconstructing the Gondwanan rift, Geology, 33, 197-200, doi:10.1130/g21081.1.

Hasterok, D., and D. S. Chapman (2007), Continental thermal isostasy: 1. Methods and sensitivity, J. Geophys. Res., 112, B06414, doi:10.1029/ 2006JB004663.

Hauck, M. L., K. D. Nelson, L. D. Brown, W. Zhao, and A. R. Ross (1998), Crustal structure of the Himalayan orogen at $\sim 90^{\circ}$ east longitude from Project INDEPTH deep reflection profiles, Tectonics, 17, 481-500, doi:10.1029/98TC01314.

Heeszel, D. S., D. A. Wiens, A. A. Nyblade, S. E. Hansen, M. Kanao, M. An, and Y. Zhao (2013), Rayleigh wave constraints on the structure and tectonic history of the Gamburtsev Subglacial Mountains, East Antarctica, J. Geophys. Res. Solid Earth, 118, 2138-2153, doi:10.1002/jgrb.50171.

Heiskanen, W. (1931), Isostatic tables for the reduction of gravimetric observations calculated on the basis of Airy's hypothesis, Bull. Géodésique, 30, 110-153, doi:10.1007/BF03029991.

Herrin, E., and T. Goforth (1977), Phase-matched filters: Application to the study of Rayleigh waves, Bull. Seismol. Soc. Am., 67, 1259-1275.

Herrmann, R. B., and C. J. Ammon (2002), Computer Programs in Seismology: Surface Waves, Receiver Functions, and Crustal Structure, St. Louis Univ., St. Louis, Mo.

Hirn, A., et al. (1984), Crustal structure and variability of the Himalayan border of Tibet, Nature, 307, $23-25$.

Ito, G., and P. E. van Keken (2007), Hot Spots and Melting Anomalies, in Treatise in Geophysics: Mantle Dynamics, edited by D. Bercovici, pp. 371-435, Elsevier, Amsterdam, Netherlands.

Jackson, J., D. McKenzie, K. Priestley, and B. Emmerson (2008), New views on the structure and rheology of the lithosphere, J. Geol. Soc., 165, 453-465, doi:10.1144/0016-76492007-109.

Jagadeesh, S., and S. S. Rai (2008), Thickness, composition, and evolution of the Indian Precambrian crust inferred from broadband seismological measurements, Precambrian Res., 162, 4-15, doi:10.1016/j.precamres.2007.07.009.

James, D. E., F. Niu, and J. Rokosky (2003), Crustal structure of the Kaapvaal craton and its significance for early crustal evolution, Lithos, 71, 413-429, doi:10.1016/j.lithos.2003.07.009.

Kennett, B. L. N., and E. R. Engdahl (1991), Traveltimes for global earthquake location and phase identification, Geophys. J. Int., 105, 429-465.

Kerr, A. C. (2003), 3.16 - oceanic plateaus, in Treatise on Geochemistry, edited by D. H. Heinrich and K. T. Karl, pp. 537-565, Pergamon, Oxford.

Knopoff, L., and G. Vane (1978), Age of East Antarctica from surface wave dispersion, Pure Appl. Geophys., 117, 806-815, doi:10.1007/ bf00879981.

Lal, D., N. B. W. Harris, K. K. Sharma, Z. Gu, L. Ding, T. Liu, W. Dong, M. W. Caffee, and A. J. T. Jull (2004), Erosion history of the Tibetan Plateau since the last interglacial: Constraints from the first studies of cosmogenic 10Be from Tibetan bedrock, Earth Planet. Sci. Lett., 217, 33-42, doi:10.1016/S0012-821X(03)00600-9.

Laske, G., G. Marsters, and C. Reif (2000), CRUST2.0: A new global crustal model at $2^{\circ} \times 2^{\circ}$. [Available at http://mahi.ucsd.edu/Gabi/rem.html.]

Lawrence, J. F., D. A. Wiens, A. A. Nyblade, S. Anandakrishnan, P. J. Shore, and D. Voigt (2006), Crust and upper mantle structure of the Transantarctic Mountains and surrounding regions from receiver functions, surface waves, and gravity: Implications for uplift models, Geochem. Geophys. Geosyst., 7, Q10011, doi:10.1029/2006GC001282.

LeMasurier, W. E. (2008), Neogene extension and basin deepening in the West Antarctic rift inferred from comparisons with the East African rift and other analogs, Geology, 36, 247-250, doi:10.1130/g24363a.1.

Liu, X., Y. Zhao, X. Liu, and L. Yu (2003), Geology of the grove mountains in East Antarctica, Sci. China, Ser. D Earth Sci., 46, 305-319, doi:10.1360/03yd9028.

Liu, X., B. Jahn, Y. Zhao, M. Li, H. Li, and X. Liu (2006), Late Pan-African granitoids from the grove mountains, East Antarctica: Age, origin, and tectonic implications, Precambrian Res., 145, 131-154.

Lloyd, A. J., A. A. Nyblade, D. A. Wiens, S. E. Hansen, M. Kanao, P. J. Shore, and D. Zhao (2013), Upper mantle seismic structure beneath central East Antarctica from body wave tomography: Implications for the origin of the Gamburtsev Subglacial Mountains, Geochemistry, Geophysics, Geosystems, 14, 902-920, doi:10.1002/ggge.20098.

Llubes, M., N. Florsch, B. Legresy, J. M. Lemoine, S. Loyer, D. Crossley, and F. Rémy (2003), Crustal thickness in Antarctica from CHAMP gravimetry, Earth Planet. Sci. Lett., 212, 103-117, doi:10.1016/s0012-821x(03)00245-0.

McClain, J. S., and C. A. Atallah (1986), Thickening of the oceanic crust with age, Geology, 14, 574-576, doi:10.1130/0091-7613(1986)14<574: totocw $>$ 2.0.co;2.

McKenzie, D., J. Jackson, and K. Priestley (2005), Thermal structure of oceanic and continental lithosphere, Earth Planet. Sci. Lett., 233, 337-349, doi:10.1016/j.epsl.2005.02.005.

Mohorovičić, A. (1910), Potres od 8. X. 1909, Godišnje izvješće Zagrebačkog meteorološkog opservatorija za godinu, $1909,1-56$.

Mooney, W. D. (2007), Crust and lithospheric structure-Global crustal structure, in Treatise on Geophysics, edited by S. E.-i.-C. Gerald, pp. 361-417, Elsevier, Amsterdam, Netherlands.

Mooney, W. D., G. Laske, and G. Masters (1998), CRUST5.1: A global crustal model at 5×5, J. Geophys. Res., 103, 727-747, doi:10.1029/ 97JB02122.

Morelli, A., and S. Danesi (2004), Seismological imaging of the Antarctic continental lithosphere: A review, Global Planet. Change, 42, 155-165, doi:10.1016/j.gloplacha.2003.12.005.

Müller, R. D., J.-Y. Royer, and L. A. Lawver (1993), Revised plate motions relative to the hotspots from combined Atlantic and Indian Ocean hotspot tracks, Geology, 21, 275-278, doi:10.1130/0091-7613(1993)021<0275:rpmrtt>2.3.co;2.

Nyman, D. C., and M. Landisman (1977), The display equalized filter for frequency-time analysis, Bull. Seismol. Soc. Am., 67, 393-404.

O'Donnell, J. P., and A. A. Nyblade (2014), Antarctica's hypsometry and crustal thickness: Implications for the origin of anomalous topography in East Antarctica, Earth Planet. Sci. Lett., 388, 143-155, doi:10.1016/j.epsl.2013.11.051.

Operto, S., and P. Charvis (1996), Deep structure of the southern Kerguelen Plateau (southern Indian Ocean) from ocean bottom seismometer wide-angle seismic data, J. Geophys. Res., 101, 25,077-25,103, doi:10.1029/96JB01758. 
Paige, C. C., and M. A. Saunders (1982a), Algorithm 583, LSQR: Sparse linear equations and least squares problems, ACM Trans. Math. Software, 8, 195-209.

Paige, C. C., and M. A. Saunders (1982a), LSQR: An algorithm for sparse linear equations and sparse least squares, ACM Trans. Math. Software, $8,43-71$.

Poudjom Djomani, Y. H., S. Y. O'Reilly, W. L. Griffin, and P. Morgan (2001), The density structure of subcontinental lithosphere through time, Earth Planet. Sci. Lett., 184, 605-621, doi:10.1016/s0012-821x(00)00362-9.

Reading, A. M. (2007), The seismicity of the Antarctic Plate, Geol. Soc. Am. Spec. Pap., 425, 285-298, doi:10.1130/2007.2425(18).

Ritzwoller, M. H., N. M. Shapiro, A. L. Levshin, and G. M. Leahy (2001), Crustal and upper mantle structure beneath Antarctica and surrounding oceans, J. Geophys. Res., 106, 30,645-30,670, doi:10.1029/2001JB000179.

Roult, G., D. Rouland, and J. P. Montagner (1994), Antarctica II: Upper mantle structure from velocities and anisotropy, Phys. Earth Planet. Inter., 84, 33-57, doi:10.1016/0031-9201(94)90033-7.

Sahr, K., D. White, and A. J. Kimerling (2003), Geodesic discrete global grid systems, Cartography Geogr. Inf. Sci., 30, 121-134, doi:10.1559/ 152304003100011090.

Shapiro, N. M., and M. H. Ritzwoller (2002), Monte Carlo inversion for a global shear-velocity model of the crust and upper mantle, Geophys. J. Int., 151, 88-105.

Siebert, L., and T. Simkin (2002), Volcanoes of the World: An illustrated catalog of holocene volcanoes and their eruptions, Smithsonian Institution.

Sleep, N. H. (2006), Mantle plumes from top to bottom, Earth Sci. Rev., 77, 231-271, doi:10.1016/j.earscirev.2006.03.007.

Steinhart, J. S. (1967), Mohorovičić discontinuity, in International Dictionary of Geophysics, edited by S. K. Runcorn, pp. 991-994, Pergamon, Oxford.

Studinger, M., R. E. Bell, W. R. Buck, G. D. Karner, and D. D. Blankenship (2004), Sub-ice geology inland of the Transantarctic Mountains in light of new aerogeophysical data, Earth Planet. Sci. Lett., 220, 391-408, doi:10.1016/s0012-821x(04)00066-4.

Sutherland, R. (2008), The significance of Antarctica for studies of global geodynamics, in Antarctica: A Keystone in a Changing World-Online Proceedings of the 10th International Symposium on Antarctic Earth Sciences, edited by A. K. Cooper et al., pp. kp10, The Nat. Acad. Press, Washington, D. C.

Talarico, F. M., and G. Kleinschmidt (2008), Chapter 7 the antarctic continent in Gondwanaland: A tectonic review and potential research targets for future investigations, in Antarctic Climate Evolution, edited by F. Fabio and S. Martin, pp. 257-308, Elsevier.

Tassara, A. (2006), Factors controlling the crustal density structure underneath active continental margins with implications for their evolution, Geochem. Geophys. Geosyst., 7, Q01001, doi:10.1029/2005GC001040.

ten Brink, U. S., R. I. Hackney, S. Bannister, T. A. Stern, and Y. Makovsky (1997), Uplift of the Transantarctic Mountains and the bedrock beneath the East Antarctic ice sheet, J. Geophys. Res., 102, 27,603-27,621, doi:10.1029/97JB02483.

Thybo, H., I. M. Artemieva, and B. Kennett (2013), Moho: 100 years after Andrija Mohorovičić, Tectonophysics, 609, 1-8, doi:10.1016/ j.tecto.2013.10.004

Tollo, R. P., L. Corriveau, J. McLelland, and M. J. Bartholomew (2004), Proterozoic tectonic evolution of the Grenville orogen in North America: An introduction, Geol. Soc. Am. Mem., 197, 1-18, doi:10.1130/0-8137-1197-5.1.

Torsvik, T. H., C. Gaina, and T. F. Redfield (2008), Antarctica and global paleogeography: From Rodinia, through Gondwanaland and Pangea, to the birth of the southern ocean and the opening of gateways, in Antarctica: A Keystone in a Changing World-Online Proceedings of the 10th International Symposium on Antarctic Earth Sciences, edited by A. K. Cooper et al., pp. kp11, The Nat. Acad. Press, Washington, D. C.

Torsvik, T. H., B. Steinberger, M. Gurnis, and C. Gaina (2010), Plate tectonics and net lithosphere rotation over the past 150 Myr, Earth Planet. Sci. Lett., 291, 106-112, doi:10.1016/j.epsl.2009.12.055.

Trampert, J., and H. J. Woodhouse (2001), Assessment of global phase velocity models, Geophys. J. Int., 144, 165-174, doi:10.1046/ j.1365-246x.2001.00307.x.

Turcotte, D. L., and G. Schubert (2002), Geodynamics, 2nd ed., Cambridge Univ. Press, New York.

van de Flierdt, T., S. R. Hemming, S. L. Goldstein, G. E. Gehrels, and S. E. Cox (2008), Evidence against a young volcanic origin of the Gamburtsev Subglacial Mountains, Antarctica, Geophys. Res.Lett., 35, L21303, doi:10.1029/2008GL035564.

Veevers, J. J. (1994), Case for the Gamburtsev Subglacial Mountains of East Antarctica originating by mid-Carboniferous shortening of an intracratonic basin, Geology, 22, 593-596, doi:10.1130/0091-7613(1994)022<0593:cftgsm>2.3.co;2.

Veevers, J. J., and A. Saeed (2011), Age and composition of Antarctic bedrock reflected by detrital zircons, erratics, and recycled microfossils in the Prydz Bay-Wilkes Land-Ross Sea-Marie Byrd Land sector (70-240E), Gondwana Res., 20, 710-738, doi:10.1016/ j.gr.2011.03.007.

Veevers, J. J., A. Saeed, and P. E. O'Brien (2008), Provenance of the Gamburtsev Subglacial Mountains from U-Pb and Hf analysis of detrital zircons in cretaceous to quaternary sediments in Prydz Bay and beneath the Amery ice shelf, Sediment. Geol., 211, 12-32, doi:10.1016/ j.sedgeo.2008.08.003.

von Frese, R. R. B., L. V. Potts, S. B. Wells, T. E. Leftwich, H. R. Kim, J. W. Kim, A. V. Golynsky, O. Hernandez, and L. R. Gaya-Piqué (2009), GRACE gravity evidence for an impact basin in Wilkes Land, Antarctica, Geochem. Geophys. Geosyst., 10, Q02014, doi:10.1029/2008GC002149.

Wang, C.-Y. (1970), Density and constitution of the mantle, J. Geophys. Res., 75, 3264-3284, doi:10.1029/JB075i017p03264.

Watts, A. B. (2007), An overview, in Crustal and Lithosphere Dynamics, edited by G. Schubert, pp. 1-48, Elsevier, Amsterdam, Netherlands.

Wessel, P., and W. H. F. Smith (1991), Free software helps map and display data, Eos Trans. AGU, 72, 441, doi:10.1029/90EO00319.

White, R. S., D. McKenzie, and R. K. O'Nions (1992), Oceanic crustal thickness from seismic measurements and rare Earth element inversions, J. Geophys. Res., 97, 19,683-19,715, doi:10.1029/92JB01749.

Winberry, J. P., and S. Anandakrishnan (2003), Seismicity and neotectonics of West Antarctica, Geophys. Res. Lett., 30(18, 1931), doi:10.1029/ 2003GL018001

Winberry, J. P., and S. Anandakrishnan (2004), Crustal structure of the West Antarctic rift system and Marie Byrd Land hotspot, Geology, 32, 977-980, doi:10.1130/g20768.1.

Yuan, X., S. V. Sobolev, and R. Kind (2002), Moho topography in the central Andes and its geodynamic implications, Earth Planet. Sci. Lett., 199, 389-402.

Zhao, W., K. D. Nelson, J. Che, J. Quo, D. Lu, C. Wu, and X. Liu (1993), Deep seismic reflection evidence for continental underthrusting beneath southern Tibet, Nature, 366, 557-559.

Zhao, Y., B. Song, Z. Zhang, Y. Fu, C. Tingyu, Y. Wang, L. Ren, Y. Yao, J. Li, and X. Liu (1995), Early Paleozoic (Pan African) thermal event of the Larsemann Hills and its neighbours, Prydz Bay, East Antarctica, Sci. China (B), 38, 74-84. 